\title{
DO LOCAL MANAGERS GIVE LABOR AN EDGE? *
}

\section{by}

\author{
Scott E. Yonker \\ Kelley School of Business Indiana University \\ syonker@indiana.edu
}

\section{CES 13-16 April, 2013}

The research program of the Center for Economic Studies (CES) produces a wide range of economic analyses to improve the statistical programs of the U.S. Census Bureau. Many of these analyses take the form of CES research papers. The papers have not undergone the review accorded Census Bureau publications and no endorsement should be inferred. Any opinions and conclusions expressed herein are those of the author(s) and do not necessarily represent the views of the U.S. Census Bureau. All results have been reviewed to ensure that no confidential information is disclosed. Republication in whole or part must be cleared with the authors.

To obtain information about the series, see www.census.gov/ces or contact Fariha Kamal, Editor, Discussion Papers, U.S. Census Bureau, Center for Economic Studies 2K132B, 4600 Silver Hill Road, Washington, DC 20233, CES.Papers.List@census.gov. 


\begin{abstract}
Based on the psychological theory of place attachments, native local managers should be more rooted in their communities than non-locals and should act accordingly. Consistent with this, local managers are 33\% less likely to lay of employees than their non-local industry peers following industry distress. Additionally, when managers are forced to lay off employees, establishments near managers' homes are less likely to experience layoffs than those located elsewhere. Locals pay for these higher employment levels by spending cash, cutting investment, and selling assets. While there is no direct evidence that labor-friendly policies of locals have a differential impact on firm performance or value, only locals with weaker incentives implement these policies, suggesting that favoritism by locals may be suboptimal. Taken together these results suggest that managerial preferences impact corporate employment decisions.
\end{abstract}

DISCLAIMER: Any opinions and conclusions expressed herein are those of the author(s) and do not necessarily represent the views of the U.S. Census Bureau. All results have been reviewed to ensure that no confidential information is disclosed.

*Contact: Scott E. Yonker, Assistant Professor, Kelley School of Business, Indiana University, Bloomington, Indiana, 47405. I would like to thank Andrew Ellul, Mara Faccio, Andrew Karolyi, Bernadette Minton, Veronika Pool, Noah Stoffman, and Ren`e Stulz for helpful comments and seminar participants at the State of Indiana Finance Conference. Support for this research at the Ann Arbor RDC from NSF(ITR-0427889) is also gratefully acknowledged. 
There is substantial evidence that the individual "styles" of managers influence corporate policies (Bertrand and Schoar, 2003). While empirical support exists for their influence on the real economic outcomes of investment (Malmendier and Tate, 2005) and output (Adams et al., 2005; Malmendier and Tate, 2009; Bennedsen et al., 2011; Kaplan et al., 2012; Mehrotra et al., 2011), the literature is silent on whether managerial heterogeneity matters for a third component of the real economy-employment. This paper seeks to fill this void by identifying managers who are likely to be more empathetic toward their workers and testing whether they implement more labor-friendly employment policies than their peers.

The difficulty in conducting such a test is finding an observable managerial characteristic that is likely to provide information about the relative strength of managers' affinities for their employees. I focus on the childhood origin of managers, hypothesizing that those who grew up near the corporate headquarters (locals) will be more rooted in their communities than those who did not, making them more likely to favor labor. This hypothesis is based on the well-documented environmental psychology concepts of place attachment (Fischer et al., 1977; Altman and Low, 1992; Hidalgo and Hernandez, 2001) and place identity (Proshansky, 1978). ${ }^{1}$

Place attachment "is an affective bond that people establish with specific areas where they prefer to remain and where they feel comfortable and safe", while place identity is "a component of personal identity, a process by which, through interaction with places, people describe themselves as belonging to a specific place" (Hernández et al., 2007, p. 311). These bonds are stronger the longer one resides in the area, when close friends and relatives live nearby (Mesch and Manor, 1998), and when native to the area (Hernández et al., 2007). Each of these suggest that locals should be more rooted in their communities than non-locals.

Empirical evidence also suggests that local managers have a greater attachment to their firms' locations than non-locals. Yonker (2012) shows that a high incidence of local managers exists among public firms largely because these managers prefer to locate close to their childhood homes. Consistent with this, local CEOs accept lower compensation than their non-local peers and are

\footnotetext{
${ }^{1}$ For a review of this literature see Manzo (2003) and Gieryn (2000). These concepts are also related to community attachment, sense of community, rootedness, and place dependence.
} 
substantially less likely to leave their firms. ${ }^{2}$ In other words, these CEOs are place attached their corporate headquarters locations.

Importantly, place attachments affect behavior. Those with greater attachment are more likely to invest their time and money in their place of attachment (Manzo and Perkins, 2006). For example, urban revitalizations are more successful in neighborhoods with long-time residents (Brown et al., 2003) and introducing youths to natural settings leads them to engage in more environmentally responsible behavior (Vaske and Kobrin, 2001). So it seems reasonable that local managers will be more likely than non-locals to implement policies that are beneficial to their local communities. One way this could manifest itself is through employment policies.

To test this, I employ an empirical methodology that is similar to that of Opler and Titman (1994). The basic idea is that negative shocks to industries induce managers to make decisions about how to "weather the storm." If managerial preferences affect employment decisions, then managers who favor their workers will be more likely to make decisions that benefit their employees following these downturns. Specifically, when managers are forced to make cuts, I expect that local managers (those who are native to the area) will be less likely than non-locals to cut employment and will be more likely to make cuts in other areas, such as investment spending or payouts to shareholders.

Consistent with locals being more empathetic toward their workers, employment growth of firms run by local managers is 0.034 higher than that of firms run by their non-local industry peers following industry downturns. This implies a large economic effect. Since the average firm in the sample employs roughly 22 thousand workers, the average firm run by a local manager keeps about 730 more employees working during times of distress than does a similar firm run by a non-local. When investigating layoffs, firms run by locals are $33 \%$ less likely than those run by non-locals to cut the workforce by at least $10 \%$ in response to industry distress. However, for large-scale layoffs (of $20 \%$ or more) there is no differential effect of local managers, suggesting that there are limits to the influence of managers' preferences on employment decisions.

How then do local managers pay for their relatively higher employment levels following distress? The analysis shows that firms run by local managers reduce investment more, spend more cash,

\footnotetext{
${ }^{2}$ The lower pay is interpreted as the geographic preferences of CEOs being a compensating differential.
} 
and sell more assets, than do firms run by their non-local peers following distress, suggesting the preferred trade-off of local managers.

Of course place attachments are not the only reason why locals may implement different policies than non-locals. There is a large literature that shows that locals possess superior information. For example, mutual fund managers tilt their portfolios toward nearby firms and outperform in these holdings (Coval and Moskowitz, 1999, 2001), individual investors also overweight and outperform in local stocks (Ivković and Weisbenner, 2005), and local analysts make more accurate forecast than their peers (Malloy, 2005). While the definition of "local" in these articles differs substantially from that used in this paper, it is also possible that managers who are native to the area of their corporate headquarters have better information than their peers. They may have a greater understanding of local business conditions or be better connected to local politicians, for example. Locals having better information, however, does not predict that they will act favorably toward labor, on average, since local managers can have both positive and negative information about their workers.

The most plausible alternative, is that local managers are more likely pursue the quiet life than their non-local peers. The "quiet life" literature shows that when weaker governance mechanisms are in place, managers will pursue policies that make their social interactions within the local community more pleasant. In these situations managers tend to pay their workers more and are less likely to open and close plants (Bertrand and Mullainathan, 2003). Consistent with this theory, Landier, Nair, and Wulf (2009) uncover that employees geographically further from the corporate headquarters are more likely to be laid off and Cronqvist, Heyman, Nilsson, Svaleryd, and Vlachos (2009) find that entrenched Swedish managers pay their workers more, especially when those workers are employed closer to the corporate headquarters. If locals are more rooted in the community, then they may value their local social interactions more than non-locals, making them more likely to favor their workers.

Lastly, local managers may be more likely than non-locals to form alliances with labor. Pagano and Volpin (2005) provide a theory on management's use of labor as an anti-takeover device. They argue that managers will pay workers more to gain their allegiance and this has two deterrent effects for potential acquirers. First, it buys workers' loyalties, who will then oppose takeover bids. Second, 
high wages through long-term contracts make the firm undesirable to most acquirers. Atanassov and Kim (2009) provide empirical support for this theory showing that in countries with weak investor protection and strong union laws firms sell assets to prevent layoffs, which wins managers support from labor and allows them to keep their positions.

One of the difficulties that arises when relating manager characteristics to firm policies is disentangling manager from firm effects. This is particularly true in the Opler and Titman (1994) framework, since firm fixed effects do little to address this problem. To combat this, I conduct establishment-level analysis using payroll data from the Longitudinal Business Database (LBD) asking, "When firms lay off employees, where do layoffs occur?" This setup is substantially different from the previous analysis. Instead of focusing purely on local managers, it focuses on the home origin of all managers. If managers are attached to their places of origin and these attachments bias their decisions, then managers should be friendlier to workers located near their origins, but these managers need not be local. For example, an Indiana-based firm run by a New Yorker should be less likely to lay off workers at establishments in New York than at plants in other locations. This New York CEO is not considered "local" in the earlier unconditional analysis, but the theory of place attachment suggests that he should still be empathetic toward New York-based workers. Neither the quiet life nor the alliance theories make this prediction.

Overall, the results from the establishment-level analysis indicate that managers give preferential treatment to employees located near their origins. Workers at establishments located near CEOs' homes are about $10 \%$ more likely to keep their jobs than those in other areas when their firms make large scale employment cuts. Additionally, I find no evidence that headquarters location matters for layoff decisions. This casts doubt that the quiet life theory is driving local managers implement favorable employment policies and is contrary to the findings of Landier et al. (2009).

How then are these findings related to those of the earlier unconditional layoff analysis? Since a large proportion of establishments are local (near the corporate headquarters), any large scale layoff at the firm level will result in laying off workers at local establishments. For local managers, these workers are close to the managers' childhood homes. This is not necessarily true for non-local managers. In effort to avoid layoffs close to their homes, local managers try to avoid layoffs altogether, 
while non-local managers do not. This leads to a lower incidence of layoffs at the firm level for locals than for non-locals, unconditionally.

After establishing that managers give preferential treatment to workers from their homes during difficult times, I next investigate the optimality of this decision. If it is inefficient for local managers to favor their employees, then firms with local managers that do not lay off workers following industry distress should subsequently under-perform their peers. When I investigate operating performance and firm value following distress I find no evidence that local managers do better or worse than their non-local peers. However, it may be asking too much of the data to find differences in performance at an annual frequency two and three years after the onset of distress.

Therefore, I also investigate whether the labor-friendliness of locals varies with how their incentives are aligned with their firms'. If the labor-friendly policies of local managers are driven by a bias due to place attachment, then locals will only be willing to implement these policies if their incentives are not properly aligned with that of their firms'. To test this I split the sample by measures of incentive alignment based on both pay structure and ownership structure. Consistent with locals failing to lay off employees following industry distress due to a bias, I find that locals only act more favorable toward labor in the subsamples of observations where managers have weak incentives to maximize firm value.

While neither the quiet life, nor the alliance theories can explain the results of the establishmentlevel analysis, I conclude the analysis by conducting additional tests of the quiet life and alliance theories to try to determine what exactly drives the labor-friendly policies of local managers.

Managers who pursue the quiet life are more likely to do so if they live in an environment where they are more likely to interact socially with their workers. The empirical literature uses the demographics around the corporate headquarters to measure the likelihood of these interactions, hypothesizing that interaction is more likely in rural, less populated areas. In my empirical framework, this suggests that the likelihood of local managers laying off employees following industry distress in small towns should be lower than in large towns. I split the sample based on county-level demographics and find the opposite result.

The alliance theory posits that managers are more labor-friendly for the added job security that 
they receive. I test whether locals managers have lower turnover than non-locals following industry distress and find no evidence that local CEOs are less likely to lose their jobs. However, locals do have lower turnover during normal times. This is consistent with local managers having stronger place attachments to the corporate headquarters than non-locals. I conclude that neither the quiet life, nor the alliance theories are likely driving local managers to implement labor-friendly corporate policies.

This paper is most closely related to the literatures of managerial heterogeneity and corporate policies and the emerging literature on labor and finance. ${ }^{3}$ It makes two contributions to these literatures. First it enhances our understanding of the interactions between managers, shareholders and employees by identifying a certain type of manager who is likely to show a greater affinity for his employees and providing evidence that, when forced to make tough decisions, these managers make decisions consistent with their preferences. Second it contributes the literature on the effects of managerial heterogeneity on corporate decisions. This study is the first to show that a specific observable managerial characteristic-CEO geographic origin-affects employment policies and that this bias is driven by the well-documented psychology theory of place attachment. ${ }^{4}$

The remainder of the paper is organized as follows. In section I, I discuss the empirical methodology. In section II, I discuss the sample construction and the data used in analysis. The empirical results are presented in section III. In section IV, I conclude.

\section{Methodology}

I test whether firms run by local managers are more labor-friendly than those run by non-locals by employing an empirical methodology that is similar to that of Opler and Titman (1994). ${ }^{5}$ The basic

\footnotetext{
${ }^{3}$ See Pagano and Volpin (2008) for a short review of the labor and finance literature.

${ }^{4}$ Using a combination of manager fixed effects and identifiable manager traits, researchers have found that differences in executives can help explain: corporate financing policies (Bertrand and Schoar, 2003; Malmendier et al., 2011; Cronqvist et al., 2012), corporate investment decisions (Malmendier and Tate, 2005), corporate risk-taking (Hutton et al., 2013; Cain and McKeon, 2011; Faccio et al., 2013; Roussanov and Savor, 2012), acquisitions (Malmendier and Tate, 2008; Jenter and Lewellen, 2011), executive compensation (Graham et al., 2012), and firm performance (Adams et al., 2005; Malmendier and Tate, 2009; Bennedsen et al., 2011; Kaplan et al., 2012; Mehrotra et al., 2011).

${ }^{5}$ Opler and Titman (1994) use their methodology to identify the effect of financial distress on corporate performance, but their methodology can be used to investigate how other firm characteristics affect corporate decisions during economic distress.
} 
idea is that industry downturns induce managers to make decisions about how to survive. If local managers are more labor-friendly than their non-local peers, then they will be more likely to make decisions that benefit their employees during these downturns. So I expect that local managers will be less likely to cut employment or wages and will be more likely to make cuts in other areas, such as investment spending and payouts to shareholders.

The main outcome variable tested is employment growth and more specifically negative employment growth, or layoffs. In addition to this main outcome variable, I also investigate measures of firm payouts, financing, investment, and performance, and value to gain insights into why managers with differing geographic origins implement different policies.

I refer to the year in which the outcome variables are measured as the base year. Industry economic distress and firm-level control variables are measured one year prior to the base year. In the spirit of Opler and Titman (1994), I identify industries in economic distress as those industries (by 3-digit SIC code) whose median sales growth is negative. ${ }^{6}$ Identifying distress by industry instead of by firm has the benefit of reducing concerns that the incumbent manager is the cause of the distress or more generally it avoids the endogeneity problem to the extent that distress is measured at the industry level and is not endogenously driven by firm-specific decisions. The local status of the manager is measured two years prior to the base year in order to mitigate concerns of reverse causality. ${ }^{7}$

A natural empirical framework to conduct my tests is a panel regression model with industrytime fixed effects. This setup industry-adjusts both the outcome and the explanatory variables.

\footnotetext{
${ }^{6}$ This definition of industry distress is less stringent than that used by Opler and Titman (1994) who additionally require that the distressed industry's median stock market return is less than -30 percent. They find that roughly three percent of their sample meets these criteria. I employ a broader definition of industry distress, due to the smaller sample of firms in this study. I leave whether my measure actually captures industry distress as an empirical issue.

${ }^{7}$ Doing so, however, creates the additional problem that the manager running the firm in the base year may be different from the manager two years prior, whose geographic origin is actually measured. Yonker (2012) shows firms that hire local CEOs persistently do so, which reduces this concern. In addition, in unreported results I estimate the baseline model on layoffs using the measure of local CEO at a one-year lag and measured in the base year and I find no difference in the results.
} 
Specifically, I estimate,

$$
\begin{aligned}
y_{i, j, t}= & \alpha+\lambda_{j, t}+\delta \text { Distress }_{j, t-1}+\gamma \text { Local }_{i, t-2}+\beta_{L} \text { Distress }_{j, t-1} \times \text { Local }_{i, t-2} \\
& +\Gamma X_{i, j, t-1}+\epsilon_{i, j, t}
\end{aligned}
$$

where $y_{i, j, t}$ is the outcome variable for firm $i$ in industry $j$ during year $t, \alpha$ is a constant, $\lambda_{j, t}$ is an industry-time fixed effect, Distress $s_{j, t-1}$ is an indicator variable that is one if firm $i$ 's industry is in distress at time $t-1$, Local $_{i, t-2}$ is an indicator variable that is one if firm $i$ 's CEO is local at time $t-2$, and $X_{i, j, t-1}$ is a vector of firm-level control variables measured at time $t-1$.

The within industry difference in the outcome variable during normal times attributed to local managers is estimated by $\gamma$, while the estimate of $\beta_{L}$ is interpreted as the within industry difference in the outcome variable attributed to local management induced by poor industry performance. Since we are interested in the causal effect of local managers on the outcome variable, conclusions drawn in this paper focus on $\beta_{L}$. Note that the inclusion of industry-time fixed effects means that the estimate of $\delta$ should be zero, since they industry-adjust the outcome variable each year. So, when estimating a regression with layoffs as the outcome variable, for example, without industry-time fixed effects we would expect the estimate of $\delta$ to be positive (layoffs are more likely during distress), but with their inclusion $\delta$ should be close to zero.

\section{Data}

\section{A Sample construction}

Three main databases are used in the construction of the sample; 1) S\&P's Execucomp database (Execucomp) to identify CEOs, 2) Lexis Nexis Public Records Database to identify CEO geographic origin, and 3) S\&P's Compustat database (Compustat) to construct measures of industry distress.

The analysis uses the sample of non-financial, non-utility, U.S.-based firms covered by Execucomp from 1996 to 2007. Execucomp essentially covers the S\&P 1,500. Since the analysis requires the geographic origin of each firm's CEO, the sample used in the tests is limited to firms for which these data are available. I use data on geographic origin from Yonker (2012) for the period 1997 to 2007 
and augment them with 3 additional years (1994 through 1996). Since the empirical setup requires CEO local status two years prior to the base year, the analysis is run for base years 1996 through 2007. For this period there are 15,298 firm-years covered by Execucomp, of which lagged 2-year CEO geographic origin is found for 11,863 (77.5\%) firm-year observations. Of these observations there are 1,765 unique firms and 2,879 unique CEOs. The regression analysis is further limited to firm year observations with non-missing employment growth. In total there are 11,651 observations.

Although the analysis is based on Execucomp firms, industry distress is determined using the broader sample of non-financial, non-utility, U.S.-based, publicly traded firms covered by Compustat. This sample is used to get a more precise measure of distress, since more firms in each industry are covered by Compustat. Since the distress measure is based on sales growth, to be included in the industry distress calculation I require that firms have 2-year lagged sales data. Following Opler and Titman (1994), all firms in industries that have less than four firms are also filtered out. An industry is considered distressed in the base year if the 1-year lagged sales growth of the median firm in the industry is negative, where industries are measured by 3-digit SIC codes.

Table 1 shows the distribution of firms by year for the sample of firms used in the regression analysis split by those in normal performing and distressed industries. The table shows that for 1,367 (11.5\%) of the 11,863 firm-year observations, firms operate in poorly performing industries. Firms in 124 (62\%) of the 199 3-digit SIC code industries experience distress to their industries for at least one year during the twelve-year sample period. The table also shows a large percentage of firms experiencing industry distress in the sample do so during the base years 2002 and 2003. Of the 1,367 firms in poorly performing industries 991 (72.5\%) occur in this two-year window. This is not surprising since firms in many industries performed poorly during the recession that began in March of 2001 and ended in November of 2001. This period also coincides with the bursting of the technology bubble.

\section{B Manager data and measure of local managers}

I assume that important corporate decisions must go through firms' top management, thus the data on managers focuses the Chief Executive Officer (CEO). Data from Execucomp are used to identify 
firms' CEOs and to construct control variables for other sources of heterogeneity in managers, specifically: CEO tenure, age, ownership, and whether the CEO was hired from within the firm. ${ }^{8}$ Data on CEO geographic origin are from Yonker (2012) and are augmented by an additional 3 years of data that I hand collect by searching the Lexis Nexis Online Public Records database following the procedure outlined by Yonker (2012).

The geographic origin of a CEO is determined by where the CEO obtained his social security number. Yonker (2012) collects the first five digits of CEOs' social security numbers from the Lexis Nexis Online Public Records Database, noting that the first three digits indicate the state of issuance and digits 4 and 5 indicate the sequence of issuance. Yonker (2012) argues that the first five digits of a CEOs social security number reveals where the CEO grew up. This is especially true for the particular sample of CEOs, since during the 1950s and 1960s (when most of these executives obtained their social security numbers), social security numbers were issued either for driver registrations or employment purposes. ${ }^{9}$ One particularly nice feature of the geographic origin measure is that it is endowed characteristic unlike many of the other characteristics that have been shown to affect corporate policies, such as military service or educational background.

Combining the data on CEO state of origin and firm headquarters location I construct my measure of local management. I follow Yonker (2012), who defines a local CEO as a CEO whose state of origin matches the state in which the firm is headquartered. Although this measure of local may be better for smaller states like Delaware, than larger states like California, the crudeness of the proxy only biases my tests against finding that local managers are more labor-friendly. CEOs who received their social security numbers late in life are likely to be foreign, thus I categorize any CEO who obtained his social security number after the age of 22 as foreign. These CEOs are never categorized as local.

\section{Firm-level data}

Firm-level data come from 3 main sources. Firm-level accounting variables are from Compustat. Stock market returns are from CRSP. In addition to these main sources, also utilized are county-level

\footnotetext{
${ }^{8}$ In addition, I also utilize data on founder status of CEOs which are from Fahlenbrach (2009).

${ }^{9}$ See Yonker (2012) for a detailed description of the procedure.
} 
data from the 2000 U.S. Census to construct measures of geographic and demographic attributes of firms' headquarters locations.

\section{Establishment-level data}

Establishment-level data come from the Longitudinal Business Database (LBD) created and maintained by the Center for Economic Studies (CES) at the U.S. Census Bureau. The LBD provides data at the establishment-level on total payroll, total number of employees, location, industry, and a link to the parent firm for all employers with paid employees contained in the Census Bureau's business register. A business establishment is defined as "a single physical location where business is conducted," (Jarmin and Miranda, 2002, p.5). An advantage of the LBD is that it covers all legal establishments that are in industries within the scope of the Economic Census, unlike the Longitudinal Research Database, which covers only manufacturing firms. A limitation is that the data are limited to payroll data. The LBD is available through 2005, so the analysis using these data is from 1996 through 2005. The last column of Table 1 shows the percentage of firms in the Execucomp sample that were matched to the LBD by year. Tests using the LBD sample include about $79 \%$ of the original Execucomp sample from 1996 to 2005.

\section{E Outcome variables}

The main question addressed in the paper is whether local managers are more labor-friendly than their non-local counterparts. Local managers may favor employees with either higher wages or higher levels of employment. While data on wages are extremely limited in the Compustat files, employment data is not. ${ }^{10}$ Thus, the main outcome variable investigated is labor growth and more specifically negative labor growth, or layoffs.

Labor growth rates are computed from employment data on total number of firm (establishment) employees from Compustat (LBD). Specifically, employment growth in the base year is the rate

\footnotetext{
${ }^{10}$ Compustat reports item $x l r$, which is total labor related expense, however the coverage is poor. In the sample of Execucomp firms only $8.6 \%$ of the firm-year observations report this item. Hallock (1998) reports that Compustat does not record changes in employment information as frequently as it records changes in financial variables. If this is the case, then employment growth should be equal to zero for a large number of observations. I find that only for $3.3 \%$ of firm-year observations is employment growth equal to zero. It is likely that reporting for employment variables has improved since the publishing of Hallock (1998).
} 
of growth in the total number of firm employees from one year prior to the base year to the end of the base year. Since I am interested in the decisions of managers during industry downturns, I am most interested in negative employment growth, or layoffs. Also of interest is the magnitude of the workforce reductions, I create several measures of layoffs. I report results using three different definitions of layoffs; employment growth $<0$, employment growth $<-10 \%$, and employment growth $<-20 \%$. Most of the results focus on layoffs of $10 \%$ of the workforce or more.

\section{F Summary statistics}

Panel A of Table 2 displays the summary statistics for the Execucomp sample used in the empirical tests. The average firm is large, with over 21 thousand employees. For $31 \%$ of the firm-year observations firms are run by local CEOs. Approximately $75 \%$ of firms' CEOs were hired from within the firm and $12 \%$ are founders.

The table also reports the means of outcome variables split between firm-year observations following times of normal and poor industry performance. If the measure of industry distress captures negative shocks to industries, then differences in these means should reflect distress. The table indicates that employment growth is much higher in normal times than following industry distress. In addition, each measure of layoff is about $50 \%$ more likely following industry distress than following normal times. Investment, share repurchases, Tobin's Q, and operating performance are all lower following industry distress than in normal times. Not surprisingly, dividend payouts are no different in good and bad times since they tend to be persistent, however cuts to dividends are more frequent. These findings are all consistent with negative industry median sales growth capturing negative shocks to industries.

Panel B of the table displays summary statistics from the LBD data. On average, $28 \%$ of establishments are located in the same state as their corporate headquarters. Additionally, the incidence of layoffs of $10 \%$ or more in this matched sample is quite similar to that of the Execucomp sample at about $12 \%$. The average establishment has 67 employees and the average firm has 187 establishments. 


\section{Results}

\section{A Are local managers more labor-friendly?}

In this section I formally test the main hypothesis that local managers are more labor-friendly than their non-local counterparts.

\section{A.1 Local managers and employment growth}

I begin by estimating equation 1 with employment growth as the dependent variable. If firms run by local managers are more labor-friendly than those managed by non-locals, then the estimated coefficient on the interaction between the distressed industry dummy and the ex ante local CEO dummy $\left(\beta_{L}\right)$ should be significantly positive.

Table 3 reports these regression results. ${ }^{11}$ The model in column 1 includes industry-time fixed effects, but does not control for any other firm-specific characteristics. The estimate of $\beta_{L}$ is 0.0315 and is significantly greater than zero at the $5 \%$ level, indicating that firms run by local managers have significantly greater employment growth following industry shocks than do firms run by their non-local industry peers.

The model in column 2 includes lagged firm-specific control variables to control for differences in employment growth rates across firms. Controls include the logarithm of the number of firm employees, operating performance, stock market returns, and growth opportunities. The estimates indicate that smaller firms, firms with superior accounting and stock market performance, and those with higher growth opportunities have higher employment growth rates. After controlling for these factors, the estimate on $\beta_{L}$ is virtually unchanged.

It may be important to include labor-related firm-specific control variables. In column 3, labor productivity and capital intensity are added to the specification in column 2. Both of these measures are included in the wage regression model by Cronqvist et al. (2009) and are relevant when investigating employment growth. The estimated coefficients on both of these variables are positive and significant at the $1 \%$ level. With their inclusion, the estimate of $\beta_{L}$ is 0.0341 and is still

\footnotetext{
${ }^{11}$ For these regression results and for remainder of the analysis standard errors of coefficient estimates are White (1980) heteroscedasticity-consistent standard errors, clustered at the firm level. In addition, in order to eliminate the effect of outliers, all outcome variables and control variables are winsorized at the $1 \%$ level in both tails.
} 
significant at the $5 \%$ level. For the remainder of the paper I refer to the regression model estimated in column 3 as the "baseline" specification when investigating various employment-related outcome variables.

Not only are the estimates of $\beta_{L}$ statistically significant, but the magnitude of the estimates indicate that local managers' effect on employment growth is economically significant, as well. This estimated effect is over $50 \%$ of the average annual employment growth rate in the sample. In terms of jobs, since the average firm has about 22,000 employees, this suggests that at the average distressed sample firm, local managers keep over 700 more employees working following times of economic distress than do their non-local counterparts. ${ }^{12}$

\section{A.2 Local managers and layoffs}

Overall the evidence in Table 3, is supportive of the hypothesis that local managers implement more labor-friendly policies than their non-local counterparts. However, since the identification of the local managers' behavior comes during times of industry distress, it might be more informative to look at reductions in employment levels. If local managers are more labor-friendly, then they should be less likely to lay off workers than their peers during difficult times.

In Table 4, equation 1 is estimated using a linear probability model where the dependent variable is a dummy variable that indicates whether the firm lays off workers during the base year. A linear probability model is utilized since the interpretation of coefficients on interaction terms in linear probability models is straightforward, whereas it is not for other binary response models. This is important since, as in the previous section, $\beta_{L}$ is the coefficient of interest. If local managers are more labor-friendly, then $\beta_{L}$ should be negative, indicating that locals are less likely to lay off employees. The regression models with the same control variables as those in columns 1 through 3 of Table 3 are estimated in the table using three alternative definitions of layoffs.

In columns 1 through 3, layoffs are defined as negative employment growth in the base year.

\footnotetext{
${ }^{12}$ Note that the coefficient on the distressed industry dummy $(\delta)$ is not statistically different from zero for any of the specifications. As explained earlier, this is to be expected since industry-time fixed effects are included in the models. Table A1 in the appendix estimates the baseline model for employment growth and layoffs with industry and time fixed effects. The estimate of $\delta$ in these specifications is significantly negative for employment growth, indicating that employment growth is lower following industry distress.
} 
In $36 \%$ of the firm-year observations a layoff occurs under this definition. In all three models, the estimate of $\beta_{L}$ is negative and significant at the $5 \%$ level. In the baseline specification (column 3 ), the estimate of $\beta_{L}$ is -0.0823 . This suggests that firms run by local managers lay off workers with 0.0823 lower probability than their non-local industry peers following periods of poor industry performance. Among the sample of firms experiencing industry distress the probability of a layoff under this definition is 0.524 . The estimate of $\beta_{L}$ suggests that having a local manager reduces this probability by about $16 \%$.

Columns 4 through 6 report analogous regression results, where layoffs are defined as employment growth less than $-10 \%$ in the base year. The estimate of $\beta_{L}$ under this definition of layoffs is again significantly negative at the $5 \%$ level in all 3 model specifications and in the baseline model is -.0616. Since the percentage of firms in distressed industries that experience a layoff of $10 \%$ or more of the workforce is $18.8 \%$, this estimate implies that firms run by local managers are $33 \%$ less likely to make these workforce cuts than their industry peers.

Large workforce reductions (20\% or more of the workforce) are investigated in columns 7 through 9 of the table. These layoffs only occur in $5.8 \%$ of the firm-year observations in the sample. In all 3 specifications the estimate of $\beta_{L}$ is negative, but not statistically different from zero. This suggests that there is little room for discretion for such large restructuring decisions or that there are limits to the ability of managers to imprint their preferences on corporate decisions. ${ }^{13}$

\section{A.3 Effects of other manager characteristics}

It is possible that the ex ante local CEO measure proxies for some other manager characteristic that influences managers to implement more labor-friendly policies following industry downturns. This is investigated in Table 5, which shows the results of estimating equation 1 with layoffs of $10 \%$ or more as the dependent variable. The specification used in the tests follows the baseline specification, but includes two additional terms; the manager characteristic being tested and the interaction of that characteristic with the industry distress dummy. All CEO characteristics are

\footnotetext{
${ }^{13}$ Atanassov and Kim (2009) find that in countries with weak investor protection and strong labor laws that managers can prevent layoffs and do so by selling assets at the expense of shareholders. Their measures indicate that the U.S. is below the median in labor strength and at the median for investor protections.
} 
measured two years prior to the base year to mitigate concerns of reverse causality. If some other CEO characteristic is driving the relationship between the ex ante local CEO dummy and layoffs, then the coefficient on the interaction term with the additional CEO characteristic should enter into the regression significantly and should diminish the significance of $\beta_{L}$.

Yonker (2012) documents that a high percentage of local CEOs are hired internally. It is possible that CEOs who are insiders interact more with their employees than do those who were hired externally. This may be because insiders are likely to have worked alongside their employees at one time. These increased social interactions could cause insiders to put a greater weight on the welfare of their employees. The model in column 1 of the table includes a dummy variable that is one if the CEO is hired from within the firm and the interaction of this variable with the distressed industry dummy. The estimated coefficient on this interaction term is indistinguishable from zero, indicating that insiders are not less likely than outsiders to cut workers following industry downturns. The estimate of $\beta_{L}$ is virtually unchanged from the earlier estimate in column 6 of Table 4 and remains significant at the $5 \%$ level.

CEOs who are founders of their companies may have a differential effect on employment policies. In column $2, \mathrm{I}$ include a dummy variable that is one if the ex ante CEO is the founder of the company and an interaction term between this dummy variable and the industry distress indicator. The regressions results indicate that founders are not less likely to lay off employees following shocks to the industry and again the estimate of $\beta_{L}$ remains negative and significant at the $5 \%$ level.

Longer CEO tenure could be a sign of entrenchment or it could signal how rooted in the community the CEO has become. In both cases longer tenure should be associated with a lower likelihood of laying off workers. In column 3, the coefficient estimate on the interaction between the natural log of ex ante CEO tenure and the distress dummy do not indicate that this is the case. Importantly, the effect of tenure on layoffs during industry downturns has little effect on the estimate of $\beta_{L}$, which is -0.0531 and is significant at the $5 \%$ level.

Cronqvist et al. (2009) show that entrenched managers pay their workers more. They argue that these managers do this in pursuit of the "quiet life." Another way that entrenched managers can treat their employees better is by giving those employees greater employment stability. If entrenched 
managers pursue the "quiet life", then they should be less likely to lay off workers. I therefore construct a measure of entrenchment based on the equity holdings of CEOs. Following the findings of Morck, Shleifer, and Vishny (1988), I define a manager to be entrenched if he holds between 5\% and $25 \%$ of his firm's equity.

The model in column 4 of the table includes a dummy variable for ex ante CEO entrenchment and the interaction of this dummy variable with the indicator of industry distress. The estimate on the interaction term suggest that during industry distress, firms run by entrenched managers have no lower probability of laying of workers. The inclusion of this entrenchment measure has virtually no effect on the magnitude nor the significance of the estimate of $\beta_{L}$.

\section{B Where do managers layoff workers?}

To this point, the evidence indicates that firms run by local managers are substantially less likely to make cuts to labor following industry distress. However, it is difficult to disentangle whether it is the preferences of local managers driving these decisions or that firms that are less likely to lay off employees tend to hire local managers. One way to separate these two possibilities is by asking, "when managers cut the workforce, where do they make the cuts?" To answer this question I merge the Execucomp sample with establishment-level payroll data from the LBD and estimate the following regression at the establishment level:

$$
y_{i, p, t}=\alpha+\delta_{i}+\beta_{h} \text { CeoHome } e_{i, t-1}+\Gamma X_{i, p, t-1}+\epsilon_{i, p, t},
$$

where $y_{i, p, t}$ is a dummy variable that is one if there is a layoff at establishment $p$ and is zero otherwise, $\alpha$ is a constant, $\delta_{i}$ is a firm fixed effect, $\mathrm{CeoHome}_{i, t-1}$ is a dummy variable that is one if the CEO's home state is equal to the state where the establishment is located and is zero otherwise, and $X_{i, p, t-1}$ is a vector of establishment-level control variables.

The coefficient of interest in this regression is $\beta_{h}$, which is the within-firm marginal effect of establishment $p$ being located in the CEO's home state on the probability of laying off workers at establishment $p$. If CEOs' layoff decisions are influenced by their empathy for workers in their home state, then we would expect to find $\beta_{h}$ to be significantly negatively estimated. Neither the quiet 
life nor the alliance theories make this prediction.

Of course this set up is substantially different from the previous analysis. Instead of focusing purely on local CEOs, it focuses on the home state of all CEOs. This is purely a test of whether CEOs, in general, favor employees in their home states. Finding that CEOs exhibit a preference for their home state in this empirical framework however, is suggestive that CEO choices and not firm-specific omitted variables are driving the results in the previous sections. If for example, a CEO from California who works at a firm headquartered in Indiana is less likely to lay off workers in California, then this is evidence that where the CEO grew up influences corporate employment decisions, even though this CEO would not be considered a local CEO.

The results of the tests are displayed in Table 6 and are run for the sample of firms whose firm-level domestic employment growth is less than $-10 \%$ in year $t$. The dependent variable in the regressions is a dummy variable that is one if the employment growth of the establishment is less than $-10 \%$ in year $t$. Thus, the regression seeks to estimate which factors contribute to the probability that a given establishment experiences a layoff when the firm has decided to layoff a large proportion of the workforce.

The regression in column 1 controls for establishment size with the natural logarithm of lagged number of establishment employees and the relative importance of the establishment to the firm with the proportion of the firm's employees at the establishment and whether the establishment is in the same industry as the firm (by 3-digit-SIC code). The results indicate that larger establishments and establishments with a greater fraction of firm employees are more likely to experience layoffs. Most interestingly, establishments located in the CEO's home state are less likely to experience layoffs than similar establishments within the firm. The estimate of $\beta_{h}$ is -0.037 and is significant at better than the 1\%-level. Given that the probability of an establishment experiencing a layoff of $10 \%$ or more when the firm experiences a layoff is $63 \%$, this indicates that establishments located in the same state as where the CEO grew up are about $10 \%(0.037 /(1-0.63))$ more likely to avoid layoffs.

Landier et al. (2009) find that divisions in the same state as the firm's headquarters are less likely to experience layoffs. The model in column 2 includes a dummy variable that is one if the 
establishment and the firm are located in the same state and is zero otherwise, as well as, a dummy variable that is one if the establishment and the firm headquarters are located in the same state as where the CEO grew up. Including these controls does not significantly alter the estimate on $\beta_{h}$, nor its significance level. Interestingly, CEOs' favoritism toward their home-state workers is not enhanced when their home states are in the the same state as their firms' headquarters. This casts doubt on the "quiet life" theory, since CEOs are likely to live near the firm headquarters.

In columns 3 and 4, additional establishment-level controls are added to control for lagged establishment employment growth, and the logarithm of average establishment wage to control for differences in human capital across establishments. The estimate of $\beta_{h}$ in column 3 is not significantly altered, but once we control for the average ability of the workforce the estimate drops in magnitude to -0.0204 , but is still significant at the $5 \%$-level.

Finally, the model estimated in column 5, includes establishment-state fixed effects to control for differences in unionization laws and other unobserved variation across states. The estimate on $\beta_{h}$ decreases slightly to -0.0223 and remains significant. ${ }^{14}$

Overall, the results from this section are consistent with the psychological theory of place attachment. Managers give preferential treatment to employees located in their home states. How then are these results related to the previous result that firms run by local managers are less likely to experience layoffs following industry distress? Table 2 reports that, on average, $28 \%$ of establishments are local and the percentage of local employees is likely much greater. For local managers this implies that any layoff at the firm level will likely result in jobs being cut from his home state, however, for non-local managers this is not necessarily true. Thus, local managers should be unconditionally less likely to lay off workers than non-locals in attempt to avoid lay offs in their native states.

\section{How do local managers finance higher employment levels?}

The results to this point show that firms managed by local CEOs are less likely to lay off workers following industry distress than firms run by their non-local industry peers and that the mechanism

\footnotetext{
${ }^{14}$ All of the results in this section are robust to using distance measures from CEO home states instead of dummy variables (unreported).
} 
driving this is likely to be the empathy that CEOs have toward workers in their home states. How then do local CEOs pay for these relatively higher levels of employment? If they are not cutting the workforce, then they must make cuts somewhere else in the firm. In this section, I investigate several ways that local managers could finance these relatively higher employment levels. Specifically, I ask whether following industry downturns local managers are more likely to: reduce payouts to shareholders, reduce investment, spend cash, increase debt, or sell assets.

To do so, I first estimate equation 1 with dividend cuts, changes in share repurchases, changes in investment, changes in cash holdings, changes in leverage, and asset sales as the dependent variables in the regressions. In these specifications, $\beta_{L}$ indicates the differential behavior of local managers from their non-local industry peers following industry distress, on average. Each regression includes firm-specific lagged control variables, but only the coefficients and standard errors of the variables of interest are reported for brevity. ${ }^{15}$

Panel A of Table 7 reports the regression results. Following industry distress, local CEOs decrease investment and spend down cash relative to their non-local industry peers. Both decreases are estimated at the 5\% significance level. Estimating equation 1, however, does not ensure that the local managers who are not cutting employment following industry distress are the same managers who are cutting investment and spending down cash. To address this, I estimate equation 1 for the subsample of firms that do not layoff workers.

The results are presented in panel $\mathrm{B}$ of the table and confirm that the differences in investment spending and cash holdings presented in panel A are indeed driven by local managers who choose not to lay off workers. Investment and cash holdings fall by $0.75 \%$ and $1.29 \%$ of assets relative to that non-locals, respectively. In addition, asset sales are $0.14 \%$ of assets greater than those of non-locals following industry distress. This finding is consistent with evidence from Atanassov and Kim (2009) who show that managers in countries with weak shareholder protections and strong labor unions often sell firm assets to for the same reason.

\footnotetext{
${ }^{15}$ Models of dividend cuts and repurchases include firm level controls for changes in lagged assets, leverage, OROA, stock returns, cash, and stock volatility. Controls included for changes in investment, cash, and leverage follow models by Duchin et al. (2010), Bates et al. (2009), and Frank and Goyal (2009), respectively. Some of the variable definitions differ slightly from those in cited papers. Controls included for asset sales include lagged assets, leverage, OROA, stock returns, cash, and stock volatility.
} 


\section{Are higher employment levels efficient?}

Results in the previous sections show that following periods of poor industry performance, local managers are less likely than their non-local industry peers to make cuts in employment. They fund these cuts by spending down cash, cutting investment, and selling assets. The immediate effect on the firm is higher employment, lower cash, and a smaller capital stock, but is the labor friendliness of locals efficient? In this section I investigate this question.

If local managers' aversion to laying off workers is inefficient then the performance and value of their firms should decline relative to their peers following distress. I test this by estimating equation 1 for the dependent variables of operating return on assets and Tobin's Q measured 1 and 2 years after the base year. If local managers make inefficient decisions on average, then the coefficient estimate on $\beta_{L}$ should be significantly negative. If however, they make better decisions around distress, $\beta_{L}$ should be positive.

The results of the regressions are displayed in Panel A of Table 8. The estimates of $\beta_{L}$ for both operating performance and firm value are not statistically different from zero in any of the regressions. This suggests that local managers do no better or worse than non-locals following industry distress. Of course, included in these regressions are local managers who also laid off workers, so in Panel B the regressions are estimated only for firm-year observations in which no layoff occurred during the base year. Again the estimates of $\beta_{L}$ are not statistically different from zero.

While the performance and value results are not supportive of the hypothesis that local managers make inefficient employment decisions following industry downturns, it may be that this direct test has little power at detecting differences in accounting performance and firm value 2 to 3 years after the onset of distress. Thus, I investigate indirect tests of the efficiency of local managers imprinting their preferences on corporate employment decisions.

If it is inefficient for local managers not to lay off workers following industry distress, then better incentive alignment should mitigate this effect. To test this I run the baseline layoff regressions for samples split by various measures of managerial incentives. In columns 1 and 2 of Table 9, I investigate managerial incentives based on pay structure, hypothesizing those with relatively more 
of their pay in the form of incentive pay will have their interests aligned better with shareholders. Specifically, I create a high incentive pay dummy variable that is one if the ratio of the CEO's incentive pay to his total pay is greater than the median in the sample. The sample is then split on this variable and column 1 shows the estimates for firms with managers with strong incentives, while column 2 shows the results for the sample of firms with weaker incentive alignment. The estimate of $\beta_{L}$ in column 1 is not statistically different from zero, while in column 2 the estimate is -0.0938 and is estimated at the $1 \%$ significance level. The results indicate that only in the sample of firms where managers have weaker incentives are local managers less likely to lay off employees following industry distress.

In columns 3 and 4 of the table, I investigate the effect of managerial ownership on layoffs. I create a dummy variable of those managers with ownership levels that are associated with better incentives. I define the incentive dummy as equal to one if the firm's CEO owns greater than zero but less than $5 \%$ of the firm. These cutoffs are based on the findings of Morck et al. (1988). For the sample, 81 percent of managers fit this definition. The table again shows that local managers are more likely to lay off workers only in the sample of firms where CEOs have weaker incentives.

\section{E Why are local managers more labor-friendly?}

In this section I provide two additional tests to try to pin down the mechanism driving local managers to favor their employees. The first test is a test of the quiet life theory and the second of the alliance theory.

The quiet life theory predicts that managers located in less populated and rural areas are more likely to pursue policies indicative of living the quiet life. To test this, I investigate how variation in the demographics of the population around the headquarters influence the propensity of local managers to favor labor following times of industry distress. I do this by estimating equation 1 using the baseline specification for layoffs for samples split by demographic characteristics. Of course finding that the local CEO effect persists within one or both or the partitioned samples also rules out that these factors are driving the relationship between local CEOs and layoffs.

The results are reported in Table 10. Landier et al. (2009) find that firms are more likely to lay 
off workers in divisions further from the corporate headquarters. Additionally, they find that this effect is limited to firms headquartered in less populated counties. They therefore attribute their findings to managers taking more labor-friendly actions for the private benefit of improved social interactions. If local managers are less likely to lay off workers for the same reasons, then layoffs by local managers should be less likely in less populated areas.

I measure less populated areas two ways. The first follows Landier et al. (2009), where I split the sample by the median of the total population in the county of the firm headquarters according the 2000 U.S. Census and the second splits the sample by the median of the percentage of the population living in rural areas in the county in which the firm is headquartered. The regression results for the partitioned samples are reported in columns 1 through 4 of the table.

The results indicate that local managers are only less likely to layoff workers following industry distress in large towns. In both small town samples (columns 1 and 3 ) the estimate of $\beta_{L}$ is not statistically different from zero. In the large town samples (columns 2 and 4), however, the estimates indicate that local managers have 0.10 and 0.11 lower probability of layoffs than firms run by non-locals. This means local managers in more populated areas are less than half as $(0.10 / 0.19)$ likely to lay off workers following industry downturns than their peers. This finding is opposite to the predictions of the quiet life theory. When coupled with earlier evidence from the establishment-level analysis that headquarters location does not matter when deciding where to lay off workers, this finding makes it unlikely that local managers make more labor-friendly employment decisions in pursuit of the quiet life.

The alliance theory hypothesizes that one reason that managers treat labor well is so that managers can retain their own positions within the firm. To test this hypothesis I estimate equation 1 using a linear probability model where the dependent variable is CEO turnover. If locals are more labor-friendly following distress for the benefit of increased job security, then the probability of turnover following distress should be lower for locals than for non-locals. In the current empirical framework, this means the $\beta_{L}$ should be negatively estimated.

The results are reported in Table 11 for the full sample in column 1 and for the sample of firm year observations where no layoffs occurred in column 2 . For both samples the estimate on $\beta_{L}$ is 
not statistically different from zero. This indicates that turnover is not less likely following distress for locals than for non-locals, which casts doubt that local managers implement labor-friendly policies to form alliances with their workers. Interestingly, and consistent with the theory of place attachments, turnover during normal times is substantially lower for locals than for non-locals. Since the unconditional probability of turnover in the sample is 0.106 , the coefficient estimate of -0.0346 implies that that turnover for local CEOs is over a third less probable than for non-locals. This is consistent with locals exhibiting a preference for living and working in the local area.

\section{Conclusion}

While researchers have shown that managerial heterogeneity affects the real economic outcomes of investment and output, employment has been neglected. This paper investigates this issue by identifying managers who are more likely to favor labor, native local managers, based on the psychology theories of place attachment and place identity and testing whether these managers implement labor-friendly corporate policies.

The results show that local managers systematically weather times of poor industry performance differently than do non-local managers. In short, these managers implement policies that favor labor. Locals are $33 \%$ less likely to cut employment following industry distress than non-locals and pay for these relatively higher employment levels by spending cash, cutting investment, and selling assets. The estimates of the differences in employment growth between firms run by locals and non-locals suggest a large economic effect. The coefficient estimates imply that the average firm in the sample run by a local manager would have over 700 more workers employed following times of distress than a similar firm run by a non-local.

When asking where layoffs occur within the firm, I find that workers near CEOs' childhood homes have about a $10 \%$ greater chance of keeping their jobs than workers in other locations. This finding makes it extremely difficult to argue that unobservable heterogeneity in firms is driving the relationship between locals and layoffs.

Place attachment is not the only theory that would suggest that locals may act more favorably toward labor than non-locals. Most prominently, the quiet life theory hypothesizes that managers 
will be kinder to employees for the benefit of better social interactions. However, given that headquarters locations do not matter in layoff decisions within firms and that the effects of locals on layoffs are not stronger in smaller, more rural areas, this quiet life theory is not likely the driver of locals propensity to implement labor-friendly policies.

Whether the labor-friendly actions of locals harms shareholders is an open issue. There is no evidence that locals under-perform their peers following distress, nor that they destroy firm value. However, only local managers with weaker incentives implement these labor-friendly policies, which begs the question why this would be the case unless favoring labor is inefficient. Nevertheless, there is no "smoking gun" showing that higher employment levels are harmful following distress.

When consolidated I draw two main conclusions from the results of this study: 1) managerial heterogeneity matters for corporate employment decisions 2) through their place attachment to their childhood homes, native local CEOs are more likely to favor labor than non-locals. 


\section{References}

Adams, R., Almeida, H., Ferreira, D., 2005. Powerful ceos and their impact on corporate performance. Review of Financial Studies 18 (4), 1403-1432.

Altman, I., Low, S., 1992. Place attachment. Plenum Press.

Atanassov, J., Kim, E., 2009. Labor and corporate governance: international evidence from restructuring decisions. Journal of Finance 64 (1), 341-374.

Bates, T., Kahle, K., Stulz, R., 2009. Why do us firms hold so much more cash than they used to? The Journal of Finance 64 (5), 1985-2021.

Bennedsen, M., Pérez-González, F., Wolfenzon, D., 2011. Do ceos matter?

Bertrand, M., Mullainathan, S., 2003. Enjoying the quiet life? corporate governance and managerial preferences. Journal of Political Economy 111 (5), 1043-1075.

Bertrand, M., Schoar, A., 2003. Managing with style: The effect of managers on firm policies. Quarterly Journal of Economics 118 (4), 1169-1208.

Brown, B., Perkins, D., Brown, G., 2003. Place attachment in a revitalizing neighborhood: Individual and block levels of analysis. Journal of environmental psychology 23 (3), 259-271.

Cain, M., McKeon, S., 2011. Cleared for takeoff? ceo personal risk-taking and corporate policies. Notre Dame and University of Oregon Working Paper.

Coval, J. D., Moskowitz, T. J., 1999. Home bias at home: Local equity preference in domestic portfolios. Journal of Finance 54 (6), 2045-2073.

Coval, J. D., Moskowitz, T. J., 2001. The geography of investment: Informed trading and asset prices. Journal of Political Economy 109 (4), 811-841.

Cronqvist, H., Heyman, F., Nilsson, M., Svaleryd, H., Vlachos, J., 2009. Do entrenched managers pay their workers more? Journal of Finance 64 (1).

Cronqvist, H., Makhija, A., Yonker, S., 2012. Behavioral consistency in corporate finance: Ceo personal and corporate leverage. Journal of financial economics 103 (1), 20-40.

Duchin, R., Ozbas, O., Sensoy, B., 2010. Costly external finance, corporate investment, and the subprime mortgage credit crisis. Forthcoming Journal of Financial Economics.

Faccio, M., Marchica, M., Mura, R., 2013. Ceo gender, corporate risk-taking, and the efficiency of capital allocation. Available at SSRN 1969782.

Fahlenbrach, R., 2009. Founder-ceos, investment decisions, and stock market performance. Journal of Financial and Quantitative Analysis 44, 439-466.

Fama, E. F., French, K. R., 2001. Disappearing dividends: Changing firm characteristics or lower propensity to pay? Journal of Financial Economics 60 (1), 3-43, englishFeature. 
Fischer, C., Stueve, C., Jones, L., Jackson, R., Gerson, K., Baldassare, M., 1977. Networks and places: Social relations in the urban setting. Free Press New York.

Frank, M. Z., Goyal, V. K., 2009. Capital structure decisions: which factors are reliably important? Financial Management 38 (1), 1-37.

Gieryn, T., 2000. A space for place in sociology. Annual review of sociology, 463-496.

Graham, J., Li, S., Qiu, J., 2012. Managerial attributes and executive compensation. Review of Financial Studies 25 (1), 144-186.

Hallock, K., 1998. Layoffs, top executive pay, and firm performance. American Economic Review 88 (4), 711-723.

Hernández, B., Carmen Hidalgo, M., Salazar-Laplace, M., Hess, S., 2007. Place attachment and place identity in natives and non-natives. Journal of environmental psychology 27 (4), 310-319.

Hidalgo, M., Hernandez, B., 2001. Place attachment: Conceptual and empirical questions. Journal of environmental psychology 21 (3), 273-281.

Hutton, I., Jiang, D., Kumar, A., 2013. Do republican managers adopt conservative corporate policies. Working paper Florida State University and University of Miami.

Ivković, Z., Weisbenner, S., 2005. Local does as local is: Information content of the geography of individual investors' common stock investments. The Journal of Finance 60 (1), 267-306.

Jarmin, R., Miranda, J., 2002. The longitudinal business database. Center for Economic Studies, $1-17$.

Jenter, D., Lewellen, K., 2011. Ceo preferences and acquisitions. Tech. rep., National Bureau of Economic Research.

Kaplan, S., Klebanov, M., Sorensen, M., 2012. Which ceo characteristics and abilities matter? The Journal of Finance 67 (3), 973-1007.

Landier, A., Nair, V., Wulf, J., 2009. Trade-offs in staying close: Corporate decision making and geographic dispersion. Review of Financial Studies 22 (3), 1119.

Malloy, C., 2005. The geography of equity analysis. The Journal of Finance 60 (2), 719-755.

Malmendier, U., Tate, G., 2005. Ceo overconfidence and corporate investment. Journal of Finance 60 (6), 2661-2700.

Malmendier, U., Tate, G., 2008. Who makes acquisitions? ceo overconfidence and the market's reaction. Journal of Financial Economics 89 (1), 20-43.

Malmendier, U., Tate, G., 2009. Superstar ceos. The Quarterly Journal of Economics 124 (4), $1593-1638$.

Malmendier, U., Tate, G., Yan, J., 2011. Overconfidence and early-life experiences: The effect of managerial traits on corporate financial policies. The Journal of Finance 66 (5), 1687-1733. 
Manzo, L., 2003. Beyond house and haven: toward a revisioning of emotional relationships with places. Journal of environmental psychology 23 (1), 47-61.

Manzo, L., Perkins, D., 2006. Finding common ground: The importance of place attachment to community participation and planning. Journal of Planning Literature 20 (4), 335-350.

Mehrotra, V., Morck, R., Shim, J., Wiwattanakantang, Y., 2011. Adoptive expectations: Rising sons in japanese family firms. Tech. rep., National Bureau of Economic Research.

Mesch, G., Manor, O., 1998. Social ties, environmental perception, and local attachment. Environment and Behavior 30 (4), 504-519.

Morck, R., Shleifer, A., Vishny, R. W., 1988. Management ownership and market valuation: An empirical analysis. Journal of Financial Economics 20, 293-315.

Opler, T. C., Titman, S. D., 1994. Financial distress and corporate performance. Journal of Finance 49 (3), 1015-1040.

Pagano, M., Volpin, P., 2005. Managers, workers, and corporate control. Journal of Finance 60 (2), $841-868$.

Pagano, M., Volpin, P., 2008. Labor and finance. Working Paper.

Proshansky, H., 1978. The city and self-identity. Environment and behavior 10 (2), 147-169.

Roussanov, N., Savor, P., 2012. Status, marriage, and managers' attitudes to risk. National Bureau of Economic Research Working Paper.

Vaske, J., Kobrin, K., 2001. Place attachment and environmentally responsible behavior. The Journal of Environmental Education 32 (4), 16-21.

White, H., 1980. A heteroskedasticity-consistent covariance matrix estimator and a direct test for heteroskedasticity. Econometrica 48, 817-838.

Yonker, S. E., 2012. Geography and the market for ceos. Indiana University Working Paper. 


\section{Appendix: Variable Definitions}

The data appendix provides definitions of variables used in the study. All accounting variables are winsorized at the $1.00 \%$ level in both tails. Variable names are given in the first column, definitions are provided in the second column, and the data source is provided in the third column.

\begin{tabular}{|c|c|c|}
\hline Variable & Definition & Source \\
\hline Employment growth & Growth in total employees & Compustat \\
\hline Dividends to assets & Common dividents / lagged book value of total assets & Compustat \\
\hline Repurchases & $\begin{array}{l}\text { Net repurchases follow Fama and French }(2001) \text {, for firms that use the treasury } \\
\text { stock method to account for repurchases the net repurchase amount is the increase } \\
\text { in the common treasury stock. For firms that use the retirement method, net } \\
\text { repurchases are the difference between total expenditure on the purchase of common } \\
\text { and preferred shares and stock issuances from the statement of cash flows. }\end{array}$ & Compustat \\
\hline Investment & Capital expenditures / lagged book value of total assets & Compustat \\
\hline Cash & Cash and short-term investments / lagged book value of total assets & Compustat \\
\hline Total debt & $\begin{array}{l}\text { (Total debt in long-term liabilities plus total debt in current liabilities) / lagged } \\
\text { book value of total assets }\end{array}$ & Compustat \\
\hline Asset sales & Sales of property, plant and equipment / lagged book value of total assets & Compustat \\
\hline OROA & Operating income before taxes and depreciation / lagged book value of total assets & Compustat \\
\hline Tobin's Q & Market-to-book ratio & Compustat \\
\hline CEO home state & State in which the CEO received his social security number. & Yonker (2012) \\
\hline Local CEO & $\begin{array}{l}\text { A dummy variable that is equal to one if the CEO state of origin is equal to firm } \\
\text { headquarter state. }\end{array}$ & Yonker (2012) \\
\hline Employees $(1,000 \mathrm{~s})$ & Total number of employees employed by the firm & Compustat \\
\hline Stock returns & Calendar year buy-and-hold return. & CRSP \\
\hline Market-to-book & Market value of total assets / book value of total assets & Compustat \\
\hline Labor productivity & Natural logaritm of total sales / total number of employees & Compustat \\
\hline Capital-to-labor ratio & Property, plant, and equipment / total number of firm employees & Compustat \\
\hline Internally hired CEO & A dummy variable that is equal to one if the CEO is hired from within the firm & Execucomp \\
\hline Founder CEO & A dummy variable that is equal to one if the CEO is the founder of the firm & Fahlenbrach (2009) \\
\hline CEO tenure & The natural logarithm of the number of years the CEO has been in office & Execucomp \\
\hline Establishment state & State in which establishment is located & LBD \\
\hline Establishment employees & Number of establishment employees & LBD \\
\hline Establishment pct. of firm employees & Establishment employees / firm employees & LBD \\
\hline
\end{tabular}

Continued on the next page. 
Continued from the previous page.

\begin{tabular}{|c|c|c|}
\hline Variable & Definition & Source \\
\hline Establishment in same industry as firm & $\begin{array}{l}\text { A dummy variable that is equal to one if the establishment and the firm have the } \\
\text { same 3-digit SIC code }\end{array}$ & LBD \\
\hline Establishment employment growth & Growth in establishment employment & LBD \\
\hline Establishment average wage & Establishment payroll / establishment employees & LBD \\
\hline $\log$ (Assets) & The natural $\log$ of the book value of assets (Millions of $2003 \$$ ) & Compustat \\
\hline Tangibility of assets & Property, plant and equipment / book value of total assets & Compustat \\
\hline$R \& D$ expenditure & R\&D expenditure / lagged book value of total assets & Compustat \\
\hline Stock volatility & Standard deviation of the daily stock return for the calendar year & CRSP \\
\hline Cash flow & Cash flow / net assets & Compustat \\
\hline Dividend payor dummy & $\begin{array}{l}\text { A dummy variable that is equal to one if the firm pays a dividend during the fiscal } \\
\text { year }\end{array}$ & Compustat \\
\hline CEO ownership pct. & Percentage of the firm owned by the firm's CEO & Execucomp \\
\hline Proportion of CEO incentive pay & Incentive compensation / total compensation & Execucomp \\
\hline Headquarter county population $(1,000 \mathrm{~s})$ & The population of county in which the firm is headquartered & 2000 U.S. Census \\
\hline Headquarter county percent rural & $\begin{array}{l}\text { The percentage of the population living in rural areas in the county in which the } \\
\text { firm is headquartered }\end{array}$ & 2000 U.S. Census \\
\hline
\end{tabular}




\section{Table A1:}

\section{Main results with industry and time fixed effects}

This table reports results for estimations of models similar to those estimated in column 3 of Table 3 and columns 3,6, and 9 of Table 4 . The models reported in this table include industry (by 3-digit SIC code) and time fixed effects, whereas those in Tables 3 and 4 include industry-time fixed effects. The sample and all variable definitions follow those in the previous tables. The table reports White (1980) heteroscedasticity-consistent standard errors, clustered at the firm-level. Significance levels are denoted by $*, * *, * * *$, which correspond to 10,5 , and 1 percent levels, respectively.

\begin{tabular}{|c|c|c|c|c|}
\hline \multirow[t]{2}{*}{ Dependent variable: } & \multirow{2}{*}{$\begin{array}{c}\text { Emp. } \\
\text { Growth } \\
(1)\end{array}$} & \multicolumn{3}{|c|}{ Employment growth $<$} \\
\hline & & $\begin{array}{l}0 \\
(2)\end{array}$ & $\begin{array}{c}-10 \% \\
(3)\end{array}$ & $\begin{array}{c}-20 \% \\
(4)\end{array}$ \\
\hline Distressed industry dummy & $\begin{array}{l}-0.0242^{* *} \\
(0.0100)\end{array}$ & $\begin{array}{c}0.0503^{* *} \\
(0.0195)\end{array}$ & $\begin{array}{c}0.0271^{*} \\
(0.0149)\end{array}$ & $\begin{array}{c}0.0033 \\
(0.0109)\end{array}$ \\
\hline Ex ante local CEO & $\begin{array}{l}-0.0073 \\
(0.0065)\end{array}$ & $\begin{array}{l}-0.0162 \\
(0.0112)\end{array}$ & $\begin{array}{l}-0.0042 \\
(0.0080)\end{array}$ & $\begin{array}{l}-0.0077 \\
(0.0052)\end{array}$ \\
\hline Distressed industry $\times$ Ex ante local CEO & $\begin{array}{l}0.0359^{* * *} \\
(0.0138)\end{array}$ & $\begin{array}{l}-0.0776^{* * *} \\
(0.0299)\end{array}$ & $\begin{array}{l}-0.0526^{* *} \\
(0.0224)\end{array}$ & $\begin{array}{l}-0.0160 \\
(0.0156)\end{array}$ \\
\hline Lagged log(employment) & $\begin{array}{l}-0.0208^{* * *} \\
(0.0022)\end{array}$ & $\begin{array}{l}0.0243^{* * *} \\
(0.0044)\end{array}$ & $\begin{array}{l}-0.0048^{*} \\
(0.0027)\end{array}$ & $\begin{array}{l}-0.0057^{* * *} \\
(0.0019)\end{array}$ \\
\hline Lagged OROA & $\begin{array}{l}0.1223^{* * *} \\
(0.0317)\end{array}$ & $\begin{array}{l}-0.4319^{* * *} \\
(0.0478)\end{array}$ & $\begin{array}{l}-0.2628^{* * *} \\
(0.0387)\end{array}$ & $\begin{array}{l}-0.1694^{* * *} \\
(0.0280)\end{array}$ \\
\hline Lagged stock returns & $\begin{array}{l}0.0762^{* * *} \\
(0.0072)\end{array}$ & $\begin{array}{l}-0.1109^{* * *} \\
(0.0087)\end{array}$ & $\begin{array}{l}-0.0799^{* * *} \\
(0.0068)\end{array}$ & $\begin{array}{l}-0.0453^{* * *} \\
(0.0047)\end{array}$ \\
\hline Lagged market-to-book & $\begin{array}{l}0.0222^{* * *} \\
(0.0027)\end{array}$ & $\begin{array}{l}-0.0326^{* * *} \\
(0.0041)\end{array}$ & $\begin{array}{l}-0.0114^{* * *} \\
(0.0030)\end{array}$ & $\begin{array}{l}-0.0070 * * * \\
(0.0018)\end{array}$ \\
\hline Lagged labor productivity & $\begin{array}{l}0.0240^{* * *} \\
(0.0076)\end{array}$ & $\begin{array}{l}-0.0119 \\
(0.0107)\end{array}$ & $\begin{array}{l}-0.0078 \\
(0.0077)\end{array}$ & $\begin{array}{l}-0.0006 \\
(0.0054)\end{array}$ \\
\hline Lagged capital to labor & $\begin{array}{l}0.0922^{* * *} \\
(0.0288)\end{array}$ & $\begin{array}{l}-0.1305^{* * *} \\
(0.0306)\end{array}$ & $\begin{array}{l}-0.0748^{* * *} \\
(0.0230)\end{array}$ & $\begin{array}{l}-0.0730^{* * *} \\
(0.0186)\end{array}$ \\
\hline Industry FE & Yes & Yes & Yes & Yes \\
\hline Time FE & Yes & Yes & Yes & Yes \\
\hline$R^{2}$ & 0.131 & 0.151 & 0.103 & 0.082 \\
\hline Observations & 11,482 & 11,482 & 11,482 & 11,482 \\
\hline Observed probability & & 0.357 & 0.129 & 0.058 \\
\hline
\end{tabular}


Table 1:

\section{Distribution of Firms by Year}

This table reports the distribution of firms by year for the sample non-financial, non-utility firms covered by the Execucomp database for which the geographic origin of two year lagged CEO is available from 1996 to 2007. The frequencies are split by those firms in normal performing and distressed industries. An industry is considered distressed in base year $t$ if the median sales growth of firms covered by Compustat in that industry in the year prior is negative. Industries are defined by 3-digit SIC codes. In addition the percentage of firms from the Execucomp sample that are matched to the U.S. Census Bureau's Longitudinal Business Database are reported. This database runs through 2005.

\begin{tabular}{lrrrrr}
\hline & $\begin{array}{c}\text { No. of firms } \\
\text { in normal perf. } \\
\text { industries }\end{array}$ & $\begin{array}{c}\text { No. of firms } \\
\text { in distressed } \\
\text { industries }\end{array}$ & $\begin{array}{c}\text { \% of firms } \\
\text { in distressed } \\
\text { industries }\end{array}$ & $\begin{array}{c}\text { No. of } \\
\text { distressed } \\
\text { industries }\end{array}$ & $\begin{array}{c}\text { \% of firms } \\
\text { matched to LBD } \\
\text { database }\end{array}$ \\
\hline 1996 & 903 & 15 & 1.6 & 7 & 84.3 \\
1997 & 886 & 28 & 3.1 & 7 & 85.3 \\
1998 & 884 & 21 & 2.3 & 11 & 83.5 \\
1999 & 817 & 118 & 12.6 & 25 & 80.5 \\
2000 & 887 & 72 & 7.5 & 20 & 78.9 \\
2001 & 966 & 57 & 5.6 & 16 & 79.8 \\
2002 & 653 & 441 & 40.3 & 73 & 75.2 \\
2003 & 517 & 550 & 51.5 & 63 & 74.2 \\
2004 & 990 & 41 & 4.0 & 17 & 75.3 \\
2005 & 1,019 & 4 & 0.4 & 3 & 72.7 \\
2006 & 1,000 & 9 & 0.9 & 4 & \\
2007 & 974 & 11 & 1.1 & 5 & \\
Total & 10,496 & 1,367 & 11.5 & 124 & 78.7 \\
\hline
\end{tabular}


Table 2:

\section{Summary statistics}

This table reports sample summary statistics for the sample of Execucomp firms. The sample includes 11,651 firm-year observations covered by the Execucomp database from 1996 through 2007. The statistics are split by firm-years during normal times and during industry distress. An industry is considered distressed in the base year $t$ if the industry median sales growth is negative during $t-1$ is negative. Industry distress is calculated using the sample of all publicly traded firms covered by Compustat, where industries are defined by 3-digit SIC codes. Variable definitions are found in the appendix. The column Diff. reports the difference between the mean of the outcome variable during normal and times of poor industry performance. Stars on the difference refer to significance levels of $t$-tests testing for differences in means of the two samples. Significance levels are denoted by $*, * *, * * *$, which correspond to 10,5 , and 1 percent levels, respectively.

\begin{tabular}{llll} 
Variable & \multicolumn{3}{c}{ Mean during } \\
Mean St. Dev. N Normal Distress Diff.
\end{tabular}

Panel A: Execucomp sample

Outcome variables (base year)

Employment growth

Employment growth $<0$

Employment growth $<-10 \%$

Employment growth $<-20 \%$

Dividend to assets

Chg. in dividend to assets

Dividend to assets chg $<-10 \%$

Repurchases to assets

Chg. in repurchases to assets

Investment

Chg. in investment

Total debt

Chg. total debt

Operating return on assets

Tobin's Q

Explanatory variables (lagged)

Ex ante local CEO

Ex ante internal hire

Ex ante founder CEO

Ex ante CEO tenure

Ex ante CEO ownership

Number of employees (1000s)

Log(employment)

Stock return

Market-to-book

Labor productivity

Capital to labor

$\log$ (assets)

Total debt

Cash

Stock volatility

Cash flow

Net working capital

R\&D expenditure

Dividend payor dummy

Acquisitions

Tangibility of assets

$\begin{array}{rrrrrr}0.068 & 0.268 & 11,651 & 0.076 & 0.009 & 0.067^{* * *} \\ 0.358 & 0.479 & 11,651 & 0.336 & 0.524 & -0.189^{* * *} \\ 0.130 & 0.336 & 11,651 & 0.122 & 0.188 & -0.066^{* * *} \\ 0.058 & 0.234 & 11,651 & 0.055 & 0.081 & -0.026^{* * *} \\ 0.012 & 0.028 & 11,635 & 0.012 & 0.011 & 0.001 \\ 0.000 & 0.027 & 11,628 & 0.000 & 0.000 & -0.001 \\ 0.103 & 0.304 & 5,894 & 0.097 & 0.150 & -0.053^{* * *} \\ 0.025 & 0.046 & 11,041 & 0.026 & 0.012 & 0.014^{* * *} \\ 0.003 & 0.045 & 10,736 & 0.003 & 0.000 & 0.004^{* * *} \\ 0.067 & 0.068 & 11,543 & 0.069 & 0.052 & 0.017^{* * *} \\ -0.005 & 0.047 & 11,417 & -0.005 & -0.008 & 0.003^{* *} \\ 0.224 & 0.188 & 11,618 & 0.224 & 0.229 & -0.005 \\ 0.004 & 0.092 & 11,598 & 0.005 & -0.008 & 0.013^{* * *} \\ 0.154 & 0.147 & 11,620 & 0.160 & 0.113 & 0.047^{* * *} \\ 2.121 & 1.560 & 11,617 & 2.168 & 1.764 & 0.405^{* * *}\end{array}$

$\begin{array}{rrr}0.314 & 0.464 & 11,651 \\ 0.756 & 0.430 & 10,394 \\ 0.118 & 0.323 & 11,651 \\ 7.485 & 7.710 & 10,834 \\ 0.031 & 0.069 & 11,182 \\ 21.615 & 62.803 & 11,651 \\ 1.784 & 1.637 & 11,651 \\ 0.180 & 0.558 & 11,651 \\ 2.191 & 1.655 & 11,619 \\ 5.324 & 0.803 & 11,651 \\ 0.126 & 0.364 & 11,622 \\ 7.158 & 1.468 & 11,651 \\ 0.221 & 0.185 & 11,612 \\ 0.148 & 0.179 & 11,647 \\ 0.029 & 0.015 & 11,562 \\ 0.021 & 0.310 & 11,601 \\ 0.086 & 0.215 & 11,338 \\ 0.041 & 0.079 & 11,562 \\ 0.507 & 0.500 & 11,638 \\ 0.034 & 0.071 & 10,881 \\ 0.292 & 0.215 & 11,622\end{array}$

Table 2 continues on the following page. 
Table 2 continues from the previous page.

Variable Mean St. Dev. N

Panel B: LBD sample

Firm characteristics

Total domestic employees (1,000's)

Firm employment growth $<-10 \%$

Number of establishments

Ex ante local CEO

Proportion of local estab.

Avg. estab. dist. to hq. state (mi.)

Avg. estab. dist. to CEO home state (mi.)

Establishment characteristics

Establishment employees

Establishment payroll ( $\$ 1,000$ 's)

Estab. state $=\mathrm{CEO}$ home state

Estab. state $=$ firm hq. state

Estab. state $=\mathrm{CEO}$ home state $=$ firm hq. state

$\log$ (distance to CEO home state)

$\log$ (distance to firm hq. state)

Log(lagged employees)

Proportion of firm employees

Estab. in same industry as firm

Log(lagged employment growth)

Log(lagged wage)

Estab. employment growth $<-10 \%$

$\begin{array}{rrr}15.242 & 45.917 & 7,771 \\ 0.123 & 0.328 & 7,771 \\ 186.689 & 696.515 & 7,771 \\ 0.343 & 0.475 & 7,771 \\ 0.279 & 0.269 & 7,771 \\ 730.989 & 425.083 & 7,771 \\ 900.758 & 492.020 & 7,771\end{array}$

67.737

$2,766.923$

0.070

0.120

0.047

6.135

5.781

3.059

0.005

0.681

0.006

3.078

0.276
$293.475 \quad 1,450,759$

$40,974.640 \quad 1,450,759$

$0.254 \quad 1,450,759$

$0.324 \quad 1,450,759$

$0.212 \quad 1,450,759$

$1.849 \quad 1,450,759$

$2.256 \quad 1,450,759$

$1.366 \quad 1,450,759$

$0.034 \quad 1,450,759$

$0.466 \quad 1,450,759$

$0.459 \quad 1,450,759$

$0.723 \quad 1,450,759$

$0.447 \quad 1,450,759$ 
Table 3:

\section{Local managers and employment growth}

This table reports the results of ordinary least squares regressions of:

$$
y_{i, j, t}=\alpha+\lambda_{j, t}+\delta \text { Distress }_{j, t-1}+\gamma \text { Local }_{i, t-2}+\beta_{L} \text { Distress }_{j, t-1} \times \text { Local }_{i, t-2}+\Gamma X_{i, j, t-1}+\epsilon_{i, j, t}
$$

where $y_{i, j, t}$ is employment growth for firm $i$ in industry $j$ during year $t, \alpha$ is a constant, $\lambda_{j, t}$ is an industry-time fixed effect, Distress $s_{j-1-1}$ is an indicator variable that is one if firm $i$ 's industry is in distress at time $t-1$, Local $_{i, t-2}$ is an indicator variable that is one if firm $i$ 's CEO is local at time $t-2$, and $X_{i, j, t-1}$ is a vector of firm-level control variables measured at time $t-1$. The sample includes 11,651 non-financial, non-utility, U.S. headquartered firms covered by the ExecuComp database from 1996 through 2007. An industry is considered distressed in the base-year if the median industry sales growth for the previous year is negative, where industries are defined by 3-digit SIC codes and the distress measure is determined using the sample of firms covered by the Compustat database. A firm's CEO is considered local if it's CEO's state of origin matches the state in which the firm is headquartered and is measured two years prior to the base-year. All lagged firm-level control variables are measured one year prior to the base-year. Definitions of these control variables are found in the appendix. The table reports White (1980) heteroscedasticity-consistent standard errors, clustered at the firm-level. All specifications include industry-time fixed effects. Significance levels are denoted by *,**, ***, which correspond to $10 \%$, $5 \%$, and $1 \%$ levels, respectively.

(1)
Distressed industry dummy

Ex ante local CEO

Distressed industry $\times$ Ex ante local CEO

Lagged $\log ($ employment)

Lagged OROA

Lagged stock returns

Lagged market-to-book

Lagged labor productivity

Lagged capital to labor

Industry-time FE

$R^{2}$

Observations

$\begin{array}{cll}-0.0313 & -0.0160 & 0.0110 \\ (0.0386) & (0.0376) & (0.0408) \\ -0.0059 & -0.0072 & -0.0065 \\ (0.0071) & (0.0069) & (0.0070) \\ 0.0315^{* *} & 0.0320^{* *} & 0.0341^{* *} \\ (0.0149) & (0.0144) & (0.0145) \\ & -0.0224^{* * *} & -0.0192^{* * *} \\ & (0.0024) & (0.0024) \\ & 0.1539^{* * *} & 0.1215^{* * *} \\ & (0.0335) & (0.0348) \\ & 0.0719 * * * & 0.0731^{* * *} \\ & (0.0081) & (0.0081) \\ & 0.0230^{* * *} & 0.0230^{* * *} \\ & (0.0028) & (0.0028) \\ & & 0.0235^{* * *} \\ & & (0.0076)\end{array}$

$0.0589^{* * *}$

$(0.0220)$

$\begin{array}{rrr}\text { Yes } & \text { Yes } & \text { Yes } \\ 0.208 & 0.270 & 0.274 \\ 11,651 & 11,497 & 11,482\end{array}$


Table 4:

\section{Local managers and layoffs}

This table reports the results of linear probability models estimated using least squares of equation 1 displayed in Table 3 , where $y_{i, j, t}$ is a dummy variable that is 1 if the employment growth of firm $i$ in industry $j$ during year $t$ is less than the indicated amount. The sample includes 11,651 non-financial, non-utility, U.S. headquartered firms covered by the ExecuComp database from 1996 through 2007. An industry is considered distressed in the base-year if the median industry sales growth for the previous year is negative, where industries are defined by 3-digit SIC codes and the distress measure is determined using the sample of firms covered by the Compustat database. A firm's CEO is considered local if it's CEO's state of origin matches the state in which the firm is headquartered and is measured two years prior to the base-year. All lagged firm-level control variables are measured one year prior to the base-year. Definitions of these control variables are found in the appendix. The table reports White (1980) heteroscedasticity-consistent standard errors, clustered at the firm-level. All specifications include industry-time fixed effects. Significance levels are denoted by $*, * *, * * *$, which correspond to $10 \%, 5 \%$, and $1 \%$ levels, respectively.

\begin{tabular}{|c|c|c|c|c|c|c|c|c|c|}
\hline & \multicolumn{9}{|c|}{ Employment growth $<$} \\
\hline & $\begin{array}{l}0 \\
(1)\end{array}$ & $\begin{array}{l}0 \\
(2)\end{array}$ & $\begin{array}{l}0 \\
(3)\end{array}$ & $\begin{array}{c}-10 \% \\
(4)\end{array}$ & $\begin{array}{c}-10 \% \\
(5)\end{array}$ & $\begin{array}{c}-10 \% \\
(6)\end{array}$ & $\begin{array}{r}-20 \% \\
(7)\end{array}$ & $\begin{array}{c}-20 \% \\
(8)\end{array}$ & $\begin{array}{l}-20 \% \\
(9)\end{array}$ \\
\hline Distressed industry dummy & $\begin{array}{c}0.0908 \\
(0.0828)\end{array}$ & $\begin{array}{c}0.0666 \\
(0.0799)\end{array}$ & $\begin{array}{c}0.0365 \\
(0.0816)\end{array}$ & $\begin{array}{c}0.0144 \\
(0.0593)\end{array}$ & $\begin{array}{l}-0.0036 \\
(0.0557)\end{array}$ & $\begin{array}{l}-0.0193 \\
(0.0577)\end{array}$ & $\begin{array}{c}0.0143 \\
(0.0460)\end{array}$ & $\begin{array}{c}0.0083 \\
(0.0473)\end{array}$ & $\begin{array}{l}-0.0068 \\
(0.0492)\end{array}$ \\
\hline Ex ante local CEO & $\begin{array}{l}-0.0139 \\
(0.0133)\end{array}$ & $\begin{array}{l}-0.0147 \\
(0.0123)\end{array}$ & $\begin{array}{l}-0.0154 \\
(0.0123)\end{array}$ & $\begin{array}{l}-0.0048 \\
(0.0087)\end{array}$ & $\begin{array}{l}-0.0067 \\
(0.0084)\end{array}$ & $\begin{array}{l}-0.0070 \\
(0.0084)\end{array}$ & $\begin{array}{l}-0.0067 \\
(0.0059)\end{array}$ & $\begin{array}{l}-0.0084 \\
(0.0057)\end{array}$ & $\begin{array}{l}-0.0086 \\
(0.0057)\end{array}$ \\
\hline Distressed industry $\times$ Ex ante local CEO & $\begin{array}{l}-0.0763^{* *} \\
(0.0346)\end{array}$ & $\begin{array}{l}-0.0802^{* *} \\
(0.0333)\end{array}$ & $\begin{array}{l}-0.0823^{* *} \\
(0.0333)\end{array}$ & $\begin{array}{l}-0.0606^{* *} \\
(0.0250)\end{array}$ & $\begin{array}{l}-0.0603^{* *} \\
(0.0244)\end{array}$ & $\begin{array}{l}-0.0616^{* *} \\
(0.0244)\end{array}$ & $\begin{array}{l}-0.0178 \\
(0.0181)\end{array}$ & $\begin{array}{l}-0.0154 \\
(0.0178)\end{array}$ & $\begin{array}{l}-0.0166 \\
(0.0178)\end{array}$ \\
\hline Lagged log(employment) & & $\begin{array}{l}0.0245^{* * *} \\
(0.0046)\end{array}$ & $\begin{array}{l}0.0224^{* * * *} \\
(0.0047)\end{array}$ & & $\begin{array}{l}-0.0046 \\
(0.0028)\end{array}$ & $\begin{array}{l}-0.0060^{* *} \\
(0.0030)\end{array}$ & & $\begin{array}{l}-0.0060^{* * *} \\
(0.0020)\end{array}$ & $\begin{array}{l}-0.0068^{* * *} \\
(0.0020)\end{array}$ \\
\hline Lagged OROA & & $\begin{array}{l}-0.4457^{* * *} \\
(0.0518)\end{array}$ & $\begin{array}{l}-0.4281^{* * *} \\
(0.0533)\end{array}$ & & $\begin{array}{l}-0.2714^{* * *} \\
(0.0370)\end{array}$ & $\begin{array}{l}-0.2593^{* * *} \\
(0.0381)\end{array}$ & & $\begin{array}{l}-0.1770^{* * *} \\
(0.0301)\end{array}$ & $\begin{array}{l}-0.1728^{* * *} \\
(0.0305)\end{array}$ \\
\hline Lagged stock returns & & $\begin{array}{l}-0.1014 * * * \\
(0.0102)\end{array}$ & $\begin{array}{l}-0.1025^{* * *} \\
(0.0102)\end{array}$ & & $\begin{array}{l}-0.0685^{* * *} \\
(0.0081)\end{array}$ & $\begin{array}{l}-0.0690^{* * *} \\
(0.0080)\end{array}$ & & $\begin{array}{l}-0.0409^{* * *} \\
(0.0056)\end{array}$ & $\begin{array}{l}-0.0412^{\text {*** }} \\
(0.0056)\end{array}$ \\
\hline Lagged market-to-book & & $\begin{array}{l}-0.0353^{* * *} \\
(0.0045)\end{array}$ & $\begin{array}{l}-0.0354^{* * *} \\
(0.0045)\end{array}$ & & $\begin{array}{l}-0.0141^{* * *} \\
(0.0032)\end{array}$ & $\begin{array}{l}-0.0141^{* * *} \\
(0.0032)\end{array}$ & & $\begin{array}{l}-0.0085^{* * *} \\
(0.0022)\end{array}$ & $\begin{array}{l}-0.0086^{* * *} \\
(0.0022)\end{array}$ \\
\hline Lagged labor productivity & & & $\begin{array}{l}-0.0092 \\
(0.0115)\end{array}$ & & & $\begin{array}{l}-0.0075 \\
(0.0080)\end{array}$ & & & $\begin{array}{l}-0.0002 \\
(0.0057)\end{array}$ \\
\hline Lagged capital to labor & & & $\begin{array}{l}-0.0818^{* * *} \\
(0.0305)\end{array}$ & & & $\begin{array}{c}-0.0400^{*} \\
(0.0213)\end{array}$ & & & $\begin{array}{l}-0.0455^{* * *} \\
(0.0169)\end{array}$ \\
\hline Industry-time FE & Yes & Yes & Yes & Yes & Yes & Yes & Yes & Yes & Yes \\
\hline$R^{2}$ & 0.237 & 0.292 & 0.292 & 0.218 & 0.254 & 0.254 & 0.193 & 0.224 & 0.225 \\
\hline Observations & 11,651 & 11,497 & 11,482 & 11,651 & 11,497 & 11,482 & 11,651 & 11,497 & 11,482 \\
\hline Observed probability & 0.3580 & 0.3570 & 0.3570 & 0.1300 & 0.1290 & 0.1290 & 0.0580 & 0.0578 & 0.0577 \\
\hline
\end{tabular}


Table 5:

\section{Effects of other manager characteristics on layoffs}

This table tests the robustness of the effects of local managers on layoffs by investigating the effect of other potentially relevant CEO characteristics on layoffs. This table reports the results of linear probability models estimated using least squares of equation 1 displayed in Table 3, where $y_{i, j, t}$ is a dummy variable that is one if the employment growth of firm $i$ in industry $j$ during year $t$ is less than $-10 \%$ and is zero otherwise. The additional CEO characteristics tested include: an indicator variable that equals one if the CEO was hired from within the firm and is zero otherwise, an indicator variable that is one if the CEO is the founder of the company and is zero otherwise, the natural log of the tenure of the firm's CEO, and an indicator variable that is one if the firm's CEO's ownership structures is between $5 \%$ and $25 \%$, as a measure of entrenchment. Each of these CEO characteristics is measured two years prior to the base-year and detailed definitions are found in the appendix. The sample and the definitions of industry distress and local CEOs are described in Tables 3. Firm-level control variables and industry-time fixed effects are included in all regressions, but their coefficients and standard errors are not reported. Industry-time fixed effects are grouped by 3-digit SIC codes. The controls include those included in the regression in column 3 of Table 3. All lagged firm-level control variables are measured one year prior to the base-year. Definitions of these control variables are found in the appendix. The table reports White (1980) heteroscedasticity-consistent standard errors, clustered at the firm-level. Significance levels are denoted by $*$, **, ***, which correspond to $10 \%, 5 \%$, and $1 \%$ levels, respectively.

$(1)$

Distressed industry dummy

Ex ante local CEO

Distressed industry $\times$ Ex ante local CEO

Ex ante Internal hire

Distressed industry $\times$ Ex ante internal hire

Ex ante founder CEO

Distressed industry $\times$ Ex ante founder CEO

Ex ante $\log ($ tenure $)$

Distressed industry $\times$ Ex ante $\log ($ tenure $)$

Ex ante entrenchment dummy $(5<$ CEO ownership $\%<25)$

Distressed industry $\times$ Ex ante entrenchment dummy

Firm-level controls

Industry-time FE

$R^{2}$

Observations
(2)

$(3)$

(4)

-0.0032
$(0.0645)$
0.0036
$(0.0092)$
$-0.0629^{* *}$
$(0.0271)$
$-0.0316^{* * *}$
$(0.0109)$
0.0098
$(0.0317)$

(0.0317)

$-0.0185$

(0.0119)

$-0.0087$

$(0.0448)$

$-0.0137^{* * *}$

(0.0043)

$-0.0021$

(0.0136)

$-0.0183$

(0.0117)

0.0024

(0.0335)

Yes
Yes
0.298
11,030

Yes
Yes
0.267
10,240

Yes
Yes
0.254
11,482

0.0155

(0.0616)

$-0.0061$

(0.0086)

$-0.0587^{* *}$

(0.0259)

Yes
Yes
0.260
10,683


Table 6:

\section{Where do managers layoff workers?}

This table reports results from establishment-level regressions of:

$$
y_{i, p, t}=\alpha+\delta_{i}+\beta_{h} \text { CeoHome }_{i, t-1}+\Gamma X_{i, p, t-1}+\epsilon_{i, p, t},
$$

where $y_{i, p, t}$ is a dummy variable that is one if there is a layoff at establishment $p$ and is zero otherwise, $\alpha$ is a constant, $\delta_{i}$ is a firm fixed effect, CeoHome $e_{i, t-1}$ is a dummy variable that is one if the CEO's home state is equal to the state where the establishment is located and is zero otherwise, and $X_{i, p, t-1}$ is a vector of establishment-level control variables. Establishment-level layoffs occur when establishment-level employment growth is less than $-10 \%$. Establishment-level data are from the LBD. The sample includes All domestic establishments of firms in the Execucomp sample that were matched to the LBD from 1996 to 2005 that experienced firm-wide layoffs of at least $10 \%$. A CEO's home state is the state in which he obtained his social security number. Definitions of control variables are found in the appendix. The table reports White (1980) heteroskedasticity-consistent standard errors, clustered at the plant-level. Firm-, time-, and plant-state-level fixed effects are included where specified. Significance levels are denoted by $* * *, * * *$, which correspond to $10 \%, 5 \%$, and $1 \%$ levels, respectively.

Dependent Variable:

Establishment employment growth $<-10 \%$

(1) (2) (3) $\quad$ (4)

(5)

Establishment in CEO home state

Establishment and firm in same state

Establishment and firm in CEO home state

Log lag establishment employees

Establishment proportion of firm employees

Establishment in same industry as firm

Log lag establishment employment growth

Log lag establishment avg. wage

Observations

Adjusted- $R^{2}$

Prob. of estab. layoff given firm layoff

Time F.E.

Firm F.E.

Establishment-state F.E.

\begin{tabular}{|c|c|c|c|c|}
\hline $\begin{array}{l}-0.0366^{* * *} \\
(0.0055)\end{array}$ & $\begin{array}{l}-0.0333^{* * *} \\
(0.0094)\end{array}$ & $\begin{array}{l}-0.0325^{* * *} \\
(0.0094)\end{array}$ & $\begin{array}{l}-0.0204^{* *} \\
(0.0093)\end{array}$ & $\begin{array}{l}-0.0223^{* *} \\
(0.0094)\end{array}$ \\
\hline & $\begin{array}{l}-0.0043 \\
(0.0056)\end{array}$ & $\begin{array}{l}-0.0051 \\
(0.0055)\end{array}$ & $\begin{array}{c}0.0124^{* *} \\
(0.0055)\end{array}$ & $\begin{array}{r}0.0105^{*} \\
(0.0057)\end{array}$ \\
\hline & $\begin{array}{l}-0.0013 \\
(0.0131)\end{array}$ & $\begin{array}{c}0.0020 \\
(0.0131)\end{array}$ & $\begin{array}{l}-0.0130 \\
(0.0129)\end{array}$ & $\begin{array}{l}-0.0017 \\
(0.0132)\end{array}$ \\
\hline $\begin{array}{l}0.0772^{* * *} \\
(0.0016)\end{array}$ & $\begin{array}{l}0.0773^{* * *} \\
(0.0016)\end{array}$ & $\begin{array}{l}0.0683^{* * *} \\
(0.0016)\end{array}$ & $\begin{array}{l}0.0596^{* * *} \\
(0.0016)\end{array}$ & $\begin{array}{l}0.0593^{* * *} \\
(0.0016)\end{array}$ \\
\hline $\begin{array}{l}0.0954^{* *} \\
(0.0400)\end{array}$ & $\begin{array}{l}0.0983^{* *} \\
(0.0401)\end{array}$ & $\begin{array}{l}0.1489^{* * *} \\
(0.0397)\end{array}$ & $\begin{array}{l}0.1865^{* * *} \\
(0.0387)\end{array}$ & $\begin{array}{l}0.1846^{* * *} \\
(0.0386)\end{array}$ \\
\hline \multirow[t]{3}{*}{$\begin{array}{c}0.0026 \\
(0.0058)\end{array}$} & $\begin{array}{c}0.0026 \\
(0.0058)\end{array}$ & $\begin{array}{c}0.0080 \\
(0.0058)\end{array}$ & $\begin{array}{l}0.0162^{* * *} \\
(0.0057)\end{array}$ & $\begin{array}{l}0.0157^{* * *} \\
(0.0057)\end{array}$ \\
\hline & & $\begin{array}{l}0.0761^{* * *} \\
(0.0029)\end{array}$ & $\begin{array}{l}0.0614^{* * *} \\
(0.0029)\end{array}$ & $\begin{array}{l}0.0610^{* * *} \\
(0.0029)\end{array}$ \\
\hline & & & $\begin{array}{l}-0.1406^{* * *} \\
(0.0033)\end{array}$ & $\begin{array}{l}-0.1420^{* * *} \\
(0.0033)\end{array}$ \\
\hline 104,508 & 104,508 & 104,508 & 104,508 & 104,508 \\
\hline 0.2520 & 0.2520 & 0.2590 & 0.2770 & 0.2780 \\
\hline 0.6271 & 0.6271 & 0.6271 & 0.6271 & 0.6271 \\
\hline Yes & Yes & Yes & Yes & Yes \\
\hline Yes & Yes & Yes & Yes & Yes \\
\hline No & No & $\mathrm{No}$ & $\mathrm{No}$ & Yes \\
\hline
\end{tabular}


Table 7:

\section{How do local managers finance higher employment?}

This table reports the results of ordinary least squares regressions of equation 1 displayed in Table 3 , where the dependent variables are a dummy variable that is one if dividends are cut by at least $10 \%$ from the previous year, changes in repurchases, changes in investment, changes in cash holdings, changes in leverage, and asset sales in columns 1 through 6 , respectively. With the exception of dividend cuts, each of the dependent variables are scaled by the book value of total assets. Panel A is estimated for the full sample and shows how the financial policies of local CEOs differ from their non-local industry peers following industry distress on average. Panel B is estimated only using firm-year observations in which no layoff occurred, showing how the financial policies of local managers who do not lay off workers following industry distress differ from their industry peers. The sample and the definitions of industry distress and local CEOs are described in Tables 3. A layoff occurs in year $t$ if employment growth is less than $-10 \%$. Models of dividend cuts and repurchases include firm level controls for changes in lagged assets, leverage, OROA, stock returns, cash, and stock volatility. Controls included for changes in investment, cash, and leverage follow models by Duchin et al. (2010), Bates et al. (2009), and Frank and Goyal (2009), respectively. Controls included for asset sales include lagged assets, OROA, stock returns, stock volatility, cash, and leverage. The table reports White (1980) heteroscedasticity-consistent standard errors, clustered at the firm-level. Industry-time fixed effects are included in all specifications, where industries are grouped by 3-digit SIC codes Significance levels are denoted by $*{ }^{* *},{ }^{* *}$, which correspond to $10 \%, 5 \%$, and $1 \%$ levels, respectively.

\begin{tabular}{|c|c|c|c|c|c|c|}
\hline & $\begin{array}{l}\text { Div. cut } \\
\text { (1) }\end{array}$ & $\Delta$ Rep. & $\Delta$ Inv. & $\underset{(4)}{\Delta \text { Cash }}$ & $\begin{array}{c}\Delta \text { Debt } \\
(5)\end{array}$ & $\begin{array}{c}\text { Asset sales } \\
\text { (6) }\end{array}$ \\
\hline \multicolumn{7}{|l|}{ Panel A: full sample } \\
\hline Distressed industry dummy & $\begin{array}{c}0.0297 \\
(0.0284)\end{array}$ & $\begin{array}{l}-0.0048 \\
(0.0083)\end{array}$ & $\begin{array}{c}0.0091 \\
(0.0074)\end{array}$ & $\begin{array}{l}-0.0090 \\
(0.0134)\end{array}$ & $\begin{array}{c}0.0183 \\
(0.0147)\end{array}$ & $\begin{array}{l}-0.0016 \\
(0.0023)\end{array}$ \\
\hline Ex ante local CEO & $\begin{array}{c}0.0074 \\
(0.0057)\end{array}$ & $\begin{array}{l}-0.0010 \\
(0.0023)\end{array}$ & $\begin{array}{c}0.0008 \\
(0.0010)\end{array}$ & $\begin{array}{l}0.0035^{* *} \\
(0.0015)\end{array}$ & $\begin{array}{c}0.0002 \\
(0.0019)\end{array}$ & $\begin{array}{c}0.0006 \\
(0.0004)\end{array}$ \\
\hline Distressed industry $\times$ Ex ante local CEO & $\begin{array}{l}-0.0239 \\
(0.0188)\end{array}$ & $\begin{array}{c}0.0023 \\
(0.0040)\end{array}$ & $\begin{array}{l}-0.0062^{* *} \\
(0.0029)\end{array}$ & $\begin{array}{l}-0.0146^{* *} \\
(0.0057)\end{array}$ & $\begin{array}{c}0.0002 \\
(0.0055)\end{array}$ & $\begin{array}{c}0.0002 \\
(0.0007)\end{array}$ \\
\hline Firm controls & Yes & Yes & Yes & Yes & Yes & Yes \\
\hline Industry-time FE & Yes & Yes & Yes & Yes & Yes & Yes \\
\hline$R^{2}$ & 0.235 & 0.183 & 0.225 & 0.167 & 0.188 & 0.334 \\
\hline Observations & 11,196 & 11,216 & 11,503 & 9,767 & 11,293 & 11,402 \\
\hline \multicolumn{7}{|c|}{ Panel B: sample of firm-year observations with no layoff } \\
\hline Distressed industry dummy & $\begin{array}{c}0.0313 \\
(0.0290)\end{array}$ & $\begin{array}{c}0.0032 \\
(0.0100)\end{array}$ & $\begin{array}{c}0.0050 \\
(0.0076)\end{array}$ & $\begin{array}{l}-0.0021 \\
(0.0092)\end{array}$ & $\begin{array}{c}0.0202 \\
(0.0143)\end{array}$ & $\begin{array}{l}-0.0016 \\
(0.0029)\end{array}$ \\
\hline Ex ante local CEO & $\begin{array}{c}0.0037 \\
(0.0057)\end{array}$ & $\begin{array}{l}-0.0002 \\
(0.0024)\end{array}$ & $\begin{array}{c}0.0006 \\
(0.0011)\end{array}$ & $\begin{array}{l}0.0038^{* *} \\
(0.0017)\end{array}$ & $\begin{array}{l}-0.0008 \\
(0.0020)\end{array}$ & $\begin{array}{c}0.0003 \\
(0.0005)\end{array}$ \\
\hline Distressed industry $\times$ Ex ante local CEO & $\begin{array}{l}-0.0237 \\
(0.0204)\end{array}$ & $\begin{array}{c}0.0046 \\
(0.0048)\end{array}$ & $\begin{array}{l}-0.0075^{* *} \\
(0.0033)\end{array}$ & $\begin{array}{l}-0.0129^{* *} \\
(0.0063)\end{array}$ & $\begin{array}{c}0.0025 \\
(0.0059)\end{array}$ & $\begin{array}{c}0.0014^{*} \\
(0.0007)\end{array}$ \\
\hline Firm controls & Yes & Yes & Yes & Yes & Yes & Yes \\
\hline Industry-time FE & Yes & Yes & Yes & Yes & Yes & Yes \\
\hline$R^{2}$ & 0.243 & 0.207 & 0.227 & 0.175 & 0.204 & 0.370 \\
\hline Observations & 9,764 & 9,779 & 10,021 & 8,524 & 9,849 & 9,928 \\
\hline
\end{tabular}


Table 8:

\section{Predicting future firm performance and value}

This table reports the results of ordinary least squares regressions, where the dependent variables are operating return on assets and Tobin's $\mathrm{Q}$ at times $t+1$ and $t+2$. The sample and the definitions of industry distress and local CEOs are described in Tables 3. Panel A shows estimates for the full sample and shows how the performance and value of firms run by local CEOs differ from that of their non-local industry peers on average. Panel B is estimated only using firm-year observations in which no layoff occurred, showing how the performance and firm value of firms run by local managers who do not lay off workers following industry distress differ from that of their industry peers. The sample and the definitions of industry distress and local CEOs are described in Tables 3 . A layoff occurs in year $t$ if employment growth is less than $-10 \%$. All lagged firm-level control variables are measured one year prior to the base-year, and include size, investment, and Tobin's Q for OROA and also include lagged OROA for the Tobin's Q regressions. Definitions of these control variables are found in the appendix. The table reports White (1980) heteroscedasticity-consistent standard errors, clustered at the firm-level. Industry-time fixed effects are included in all specifications, where industries are denoted by 3-digit SIC codes. Significance levels are denoted by $* * *, * * *$, which correspond to $10 \%, 5 \%$, and $1 \%$ levels, respectively.

\begin{tabular}{|c|c|c|c|c|}
\hline & \multicolumn{2}{|c|}{ OROA } & \multicolumn{2}{|c|}{ Tobin's Q } \\
\hline & $\begin{array}{r}t+1 \\
(1)\end{array}$ & $\begin{array}{r}t+2 \\
(2)\end{array}$ & $\begin{array}{r}t+1 \\
(3)\end{array}$ & $\begin{array}{c}t+2 \\
(4)\end{array}$ \\
\hline \multicolumn{5}{|l|}{ Panel A: full sample } \\
\hline Distressed industry dummy & $\begin{array}{c}0.0050 \\
(0.0152)\end{array}$ & $\begin{array}{c}0.0090 \\
(0.0132)\end{array}$ & $\begin{array}{l}-0.0549 \\
(0.1270)\end{array}$ & $\begin{array}{c}0.0043 \\
(0.1316)\end{array}$ \\
\hline Ex ante local CEO & $\begin{array}{l}0.0118^{* *} \\
(0.0052)\end{array}$ & $\begin{array}{l}0.0119^{* *} \\
(0.0058)\end{array}$ & $\begin{array}{l}-0.0107 \\
(0.0317)\end{array}$ & $\begin{array}{l}-0.0136 \\
(0.0400)\end{array}$ \\
\hline Distressed industry $\times$ Ex ante local CEO & $\begin{array}{c}0.0068 \\
(0.0074)\end{array}$ & $\begin{array}{c}0.0083 \\
(0.0087)\end{array}$ & $\begin{array}{c}0.0312 \\
(0.0604)\end{array}$ & $\begin{array}{l}-0.0111 \\
(0.0660)\end{array}$ \\
\hline $\begin{array}{l}\text { Firm controls } \\
\text { Industry-time FE }\end{array}$ & $\begin{array}{l}\text { Yes } \\
\text { Yes }\end{array}$ & $\begin{array}{l}\text { Yes } \\
\text { Yes }\end{array}$ & $\begin{array}{l}\text { Yes } \\
\text { Yes }\end{array}$ & $\begin{array}{l}\text { Yes } \\
\text { Yes }\end{array}$ \\
\hline $\begin{array}{l}R^{2} \\
\text { Observations }\end{array}$ & $\begin{array}{l}0.3338 \\
10,794\end{array}$ & $\begin{array}{r}0.3271 \\
9,272\end{array}$ & $\begin{array}{l}0.5819 \\
10,756\end{array}$ & $\begin{array}{r}0.5075 \\
9,257\end{array}$ \\
\hline \multicolumn{5}{|c|}{ Panel B: sample of firm-year observations with no layoff } \\
\hline Distressed industry dummy & $\begin{array}{c}0.0060 \\
(0.0162)\end{array}$ & $\begin{array}{c}0.0230^{*} \\
(0.0134)\end{array}$ & $\begin{array}{c}0.0121 \\
(0.1462)\end{array}$ & $\begin{array}{c}0.1203 \\
(0.1450)\end{array}$ \\
\hline Ex ante local CEO & $\begin{array}{l}0.0108^{* *} \\
(0.0054)\end{array}$ & $\begin{array}{c}0.0100^{*} \\
(0.0057)\end{array}$ & $\begin{array}{l}-0.0098 \\
(0.0351)\end{array}$ & $\begin{array}{c}0.0066 \\
(0.0430)\end{array}$ \\
\hline Distressed industry $\times$ Ex ante local CEO & $\begin{array}{l}-0.0002 \\
(0.0080)\end{array}$ & $\begin{array}{c}0.0048 \\
(0.0083)\end{array}$ & $\begin{array}{c}0.0592 \\
(0.0635)\end{array}$ & $\begin{array}{c}0.0316 \\
(0.0686)\end{array}$ \\
\hline Firm controls & Yes & Yes & Yes & Yes \\
\hline Industry-time FE & Yes & Yes & Yes & Yes \\
\hline $\begin{array}{l}R^{2} \\
\text { Observations }\end{array}$ & $\begin{array}{r}0.3259 \\
9,449\end{array}$ & $\begin{array}{r}0.3445 \\
8,141\end{array}$ & $\begin{array}{r}0.6046 \\
9,421\end{array}$ & $\begin{array}{r}0.5379 \\
8,128\end{array}$ \\
\hline
\end{tabular}


Table 9:

\section{Incentives and layoffs}

This table investigates the effects of managerial incentives on the relationship between local managers and layoffs by estimating the linear probability model from column 6 of Table 4, for samples splits based on various measures of managerial incentives. The dependent variable is dummy variable that is equal to one if employment growth in the base-year is less than - $10 \%$ and is zero otherwise. The sample and the definitions of industry distress and local CEOs are described in Table 3. A manager has high incentive pay if the ratio of his incentive pay to his total pay is greater than the median in the sample. A firm's CEO's ownership structure is aligned with firm incentives if the CEO's ownership percentage is greater than 0 , but less than 5 . Percentage of incentive pay and CEO ownership measures are computed using Execucomp data. Detailed definitions of these computations are in the appendix. Firm-level control variables and industry-time fixed effects are included in all regressions, but their coefficients and standard errors are not reported. Industry-time fixed effects are grouped by 3-digit SIC codes. The controls include those included in the regression in column 3 of Table 3. All lagged firm-level control variables are measured one year prior to the base-year. Definitions of these control variables are found in the appendix. The table reports White (1980) heteroscedasticity-consistent standard errors, clustered at the firm-level. Significance levels are denoted by *, **, ***, which correspond to $10 \%, 5 \%$, and $1 \%$ levels, respectively.

\begin{tabular}{|c|c|c|c|c|}
\hline & \multicolumn{2}{|c|}{ High incentive pay $=$} & \multicolumn{2}{|c|}{ Ownership incentive $=$} \\
\hline & $\begin{array}{c}1 \\
(1)\end{array}$ & $\begin{array}{c}0 \\
(2)\end{array}$ & $\begin{array}{c}1 \\
(3)\end{array}$ & $\begin{array}{c}0 \\
(4)\end{array}$ \\
\hline Distressed industry dummy & $\begin{array}{l}-0.0666 \\
(0.0974)\end{array}$ & $\begin{array}{l}-0.0228 \\
(0.0894)\end{array}$ & $\begin{array}{c}0.0142 \\
(0.0691)\end{array}$ & $\begin{array}{l}-0.0905 \\
(0.1096)\end{array}$ \\
\hline Ex ante local CEO & $\begin{array}{l}-0.0022 \\
(0.0133)\end{array}$ & $\begin{array}{l}-0.0144 \\
(0.0120)\end{array}$ & $\begin{array}{l}-0.0030 \\
(0.0098)\end{array}$ & $\begin{array}{l}-0.0180 \\
(0.0284)\end{array}$ \\
\hline Distressed industry $\times$ Ex ante local CEO & $\begin{array}{l}-0.0239 \\
(0.0448)\end{array}$ & $\begin{array}{l}-0.0938^{* * *} \\
(0.0338)\end{array}$ & $\begin{array}{l}-0.0266 \\
(0.0306)\end{array}$ & $\begin{array}{l}-0.1917^{* *} \\
(0.0818)\end{array}$ \\
\hline Lagged log(employment) & $\begin{array}{l}-0.0072 \\
(0.0044)\end{array}$ & $\begin{array}{l}-0.0088^{*} \\
(0.0046)\end{array}$ & $\begin{array}{l}-0.0057^{*} \\
(0.0034)\end{array}$ & $\begin{array}{c}0.0033 \\
(0.0117)\end{array}$ \\
\hline Lagged OROA & $\begin{array}{l}-0.3250^{* * *} \\
(0.0602)\end{array}$ & $\begin{array}{l}-0.1885^{* * *} \\
(0.0492)\end{array}$ & $\begin{array}{l}-0.2959^{* * *} \\
(0.0561)\end{array}$ & $\begin{array}{l}-0.1572^{*} \\
(0.0801)\end{array}$ \\
\hline Lagged stock returns & $\begin{array}{l}-0.0687^{* * *} \\
(0.0134)\end{array}$ & $\begin{array}{l}-0.0683^{* * *} \\
(0.0112)\end{array}$ & $\begin{array}{l}-0.0626^{* * *} \\
(0.0103)\end{array}$ & $\begin{array}{l}-0.0781^{* * *} \\
(0.0172)\end{array}$ \\
\hline Lagged market-to-book & $\begin{array}{l}-0.0122^{* * *} \\
(0.0045)\end{array}$ & $\begin{array}{l}-0.0174 * * * \\
(0.0048)\end{array}$ & $\begin{array}{l}-0.0154^{* * *} \\
(0.0044)\end{array}$ & $\begin{array}{l}-0.0142^{* *} \\
(0.0070)\end{array}$ \\
\hline Lagged labor productivity & $\begin{array}{l}-0.0150 \\
(0.0137)\end{array}$ & $\begin{array}{l}-0.0037 \\
(0.0112)\end{array}$ & $\begin{array}{l}-0.0046 \\
(0.0101)\end{array}$ & $\begin{array}{l}-0.0253 \\
(0.0277)\end{array}$ \\
\hline Lagged capital to labor & $\begin{array}{l}-0.0356 \\
(0.0441)\end{array}$ & $\begin{array}{l}-0.0699^{* *} \\
(0.0285)\end{array}$ & $\begin{array}{l}-0.0428^{*} \\
(0.0254)\end{array}$ & $\begin{array}{l}-0.1226 \\
(0.0903)\end{array}$ \\
\hline $\begin{array}{l}\text { Firm-level controls } \\
\text { Industry-time FE }\end{array}$ & $\begin{array}{l}\text { Yes } \\
\text { Yes }\end{array}$ & $\begin{array}{l}\text { Yes } \\
\text { Yes }\end{array}$ & $\begin{array}{l}\text { Yes } \\
\text { Yes }\end{array}$ & $\begin{array}{l}\text { Yes } \\
\text { Yes }\end{array}$ \\
\hline $\begin{array}{l}R^{2} \\
\text { Observations }\end{array}$ & $\begin{array}{l}0.341 \\
5,704\end{array}$ & $\begin{array}{l}0.355 \\
5,714\end{array}$ & $\begin{array}{l}0.286 \\
8,997\end{array}$ & $\begin{array}{l}0.531 \\
2,032\end{array}$ \\
\hline
\end{tabular}


Table 10:

\section{Demographics and layoffs}

This table investigates the effects of demographics around the corporate headquarters on the relationship between local managers and layoffs by estimating the linear probability model version of equation 1 , displayed in Table 3 , for samples splits based on demographics around the corporate headquarters. The dependent variable is a dummy variable that is equal to one if employment growth in the base-year is less than $-10 \%$ and is zero otherwise. The sample and the definitions of industry distress and local CEOs are described in Table 3. A firm is headquartered in a small town if the total population of the county in which the firm is headquartered is less than the median of the sample. The headquarters of a firm is considered to be in a rural area if the percentage of the population living in rural areas in the county in which the firm is headquartered is less than median of the sample. Population data are from the 2000 U.S. Census. Industry-time fixed effects are grouped by 3-digit SIC codes. All lagged firm-level control variables are measured one year prior to the base-year. Definitions of these control variables are found in the appendix. The table reports White (1980) heteroscedasticity-consistent standard errors, clustered at the firm-level. Significance levels are denoted by $*,{ }^{* *}, * * *$, which correspond to $10 \%, 5 \%$, and $1 \%$ levels, respectively.

\begin{tabular}{|c|c|c|c|c|}
\hline & \multicolumn{2}{|c|}{$\mathrm{HQ}$ in small town $=$} & \multicolumn{2}{|c|}{ HQ in rural area $=$} \\
\hline & $\begin{array}{c}1 \\
(1)\end{array}$ & $\begin{array}{c}0 \\
(2)\end{array}$ & $\begin{array}{c}1 \\
(3)\end{array}$ & $\begin{array}{c}0 \\
(4)\end{array}$ \\
\hline Distressed industry dummy & $\begin{array}{l}-0.0930 \\
(0.0748)\end{array}$ & $\begin{array}{c}0.0812 \\
(0.1228)\end{array}$ & $\begin{array}{l}-0.1404^{*} \\
(0.0720)\end{array}$ & $\begin{array}{c}0.0100 \\
(0.1194)\end{array}$ \\
\hline Ex ante local CEO & $\begin{array}{c}0.0072 \\
(0.0140)\end{array}$ & $\begin{array}{l}-0.0194 \\
(0.0130)\end{array}$ & $\begin{array}{l}-0.0010 \\
(0.0135)\end{array}$ & $\begin{array}{l}-0.0095 \\
(0.0138)\end{array}$ \\
\hline Distressed industry $\times$ Ex ante local CEO & $\begin{array}{l}-0.0187 \\
(0.0383)\end{array}$ & $\begin{array}{l}-0.0980^{* *} \\
(0.0419)\end{array}$ & $\begin{array}{l}-0.0072 \\
(0.0397)\end{array}$ & $\begin{array}{l}-0.1108^{* * *} \\
(0.0401)\end{array}$ \\
\hline Lagged log(employment) & $\begin{array}{l}-0.0023 \\
(0.0045)\end{array}$ & $\begin{array}{l}-0.0084^{*} \\
(0.0048)\end{array}$ & $\begin{array}{l}-0.0057 \\
(0.0045)\end{array}$ & $\begin{array}{l}-0.0050 \\
(0.0047)\end{array}$ \\
\hline Lagged OROA & $\begin{array}{l}-0.2334^{* * *} \\
(0.0569)\end{array}$ & $\begin{array}{l}-0.2757^{* * *} \\
(0.0565)\end{array}$ & $\begin{array}{l}-0.2975^{* * *} \\
(0.0629)\end{array}$ & $\begin{array}{l}-0.2203^{\text {*** }} \\
(0.0563)\end{array}$ \\
\hline Lagged stock returns & $\begin{array}{l}-0.0617^{* * *} \\
(0.0140)\end{array}$ & $\begin{array}{l}-0.0784^{* * *} \\
(0.0117)\end{array}$ & $\begin{array}{l}-0.0581^{* * *} \\
(0.0134)\end{array}$ & $\begin{array}{l}-0.0753^{* * *} \\
(0.0124)\end{array}$ \\
\hline Lagged market-to-book & $\begin{array}{l}-0.0131^{* * *} \\
(0.0048)\end{array}$ & $\begin{array}{l}-0.0147^{* * *} \\
(0.0050)\end{array}$ & $\begin{array}{l}-0.0125^{* *} \\
(0.0052)\end{array}$ & $\begin{array}{l}-0.0167^{* * *} \\
(0.0049)\end{array}$ \\
\hline Lagged labor productivity & $\begin{array}{l}-0.0010 \\
(0.0132)\end{array}$ & $\begin{array}{l}-0.0122 \\
(0.0119)\end{array}$ & $\begin{array}{l}-0.0023 \\
(0.0127)\end{array}$ & $\begin{array}{l}-0.0107 \\
(0.0126)\end{array}$ \\
\hline Lagged capital to labor & $\begin{array}{l}-0.0338 \\
(0.0281)\end{array}$ & $\begin{array}{c}-0.0640^{*} \\
(0.0368)\end{array}$ & $\begin{array}{l}-0.0426 \\
(0.0383)\end{array}$ & $\begin{array}{l}-0.0537 \\
(0.0329)\end{array}$ \\
\hline Industry-time FE & Yes & Yes & Yes & Yes \\
\hline$R^{2}$ & 0.355 & 0.337 & 0.349 & 0.360 \\
\hline Observations & 5,770 & 5,711 & 5,765 & 5,716 \\
\hline
\end{tabular}


Table 11:

\section{CEO turnover following distress}

This table investigates whether turnover is lower for local managers than non-locals following industry distress. The dependent variable is a dummy variable that is 1 if CEO turnover occurs in the base year. The table displays the output from the estimation of a linear probability model estimated using ordinary least squares. The regressions in column 1 use the entire sample of data and the regression in column 2 uses only firm-year observations that had employment growth greater than $-10 \%$ in the base-year. The sample and the definitions of industry distress and local CEOs are described in Table 3. Industry-time fixed effects are included in all regressions, but their coefficients and standard errors are not reported. Industry-time fixed effects are grouped by 3-digit SIC codes. All lagged firm-level control variables are measured one year prior to the base-year. Definitions of these control variables are found in the appendix. The table reports White (1980) heteroscedasticity-consistent standard errors, clustered at the firm-level. Significance levels are denoted by *, **, ***, which correspond to $10 \%, 5 \%$, and $1 \%$ levels, respectively.

\begin{tabular}{|c|c|c|}
\hline sample: & $\begin{array}{r}\text { Full } \\
(1)\end{array}$ & $\begin{array}{c}\text { No layoff } \\
(2)\end{array}$ \\
\hline Distressed industry dummy & $\begin{array}{l}-0.0420 \\
(0.0467)\end{array}$ & $\begin{array}{l}-0.0284 \\
(0.0537)\end{array}$ \\
\hline Ex ante local CEO & $\begin{array}{l}-0.0346^{* * *} \\
(0.0067)\end{array}$ & $\begin{array}{l}-0.0320^{* * *} \\
(0.0072)\end{array}$ \\
\hline Distressed industry $\times$ Ex ante local CEO & $\begin{array}{c}0.0081 \\
(0.0203)\end{array}$ & $\begin{array}{c}0.0164 \\
(0.0224)\end{array}$ \\
\hline Lagged OROA & $\begin{array}{l}-0.0889 * * * \\
(0.0294)\end{array}$ & $\begin{array}{l}-0.0952^{* * *} \\
(0.0324)\end{array}$ \\
\hline Lagged stock returns & $\begin{array}{l}-0.0344^{* * *} \\
(0.0073)\end{array}$ & $\begin{array}{l}-0.0286^{* * *} \\
(0.0079)\end{array}$ \\
\hline Lagged $\log$ (Assets) & $\begin{array}{l}0.0075^{* * *} \\
(0.0026)\end{array}$ & $\begin{array}{l}0.0106^{* * *} \\
(0.0029)\end{array}$ \\
\hline Lagged market-to-book & $\begin{array}{l}-0.0008 \\
(0.0026)\end{array}$ & $\begin{array}{c}0.0010 \\
(0.0028)\end{array}$ \\
\hline Lagged stock volatility & $\begin{array}{l}0.8480^{* *} \\
(0.3459)\end{array}$ & $\begin{array}{l}1.0317^{* *} \\
(0.4205)\end{array}$ \\
\hline $\begin{array}{l}\text { Industry-time FE } \\
R^{2} \\
\text { Observations } \\
\text { Observed probability }\end{array}$ & $\begin{array}{r}\text { Yes } \\
0.166 \\
11,414 \\
0.1062\end{array}$ & $\begin{array}{r}\text { Yes } \\
0.180 \\
9,944 \\
0.0988\end{array}$ \\
\hline
\end{tabular}

